Historic, Archive Document

Do not assume content reflects current scientific knowledge, policies, or practices. 
$2 x+3 \times=-3$

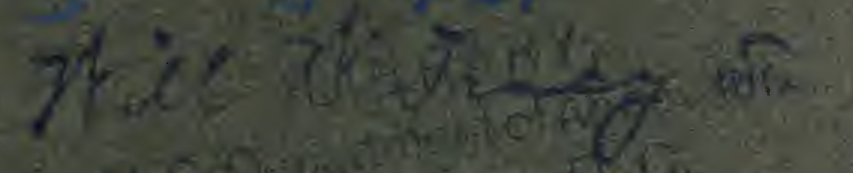

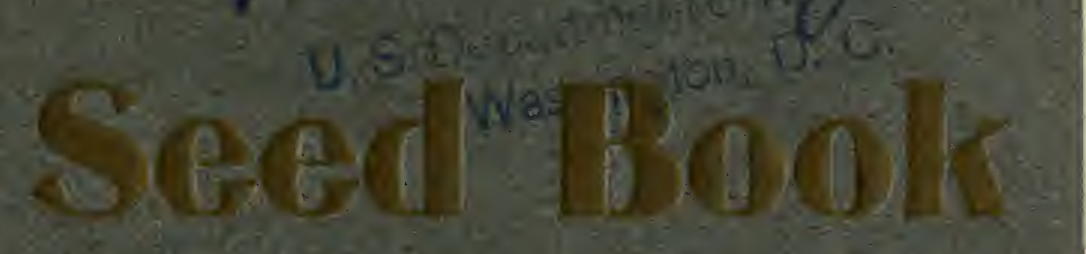

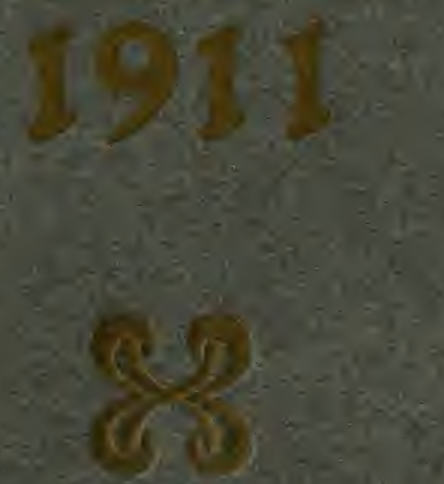

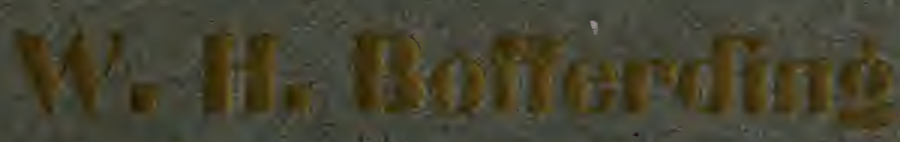

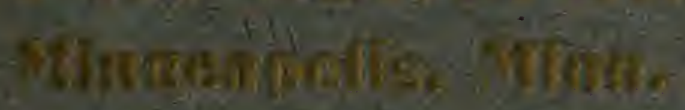




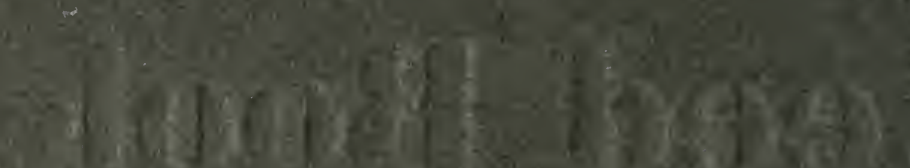
G.

$$
\text { 4. }
$$

$$
\begin{aligned}
& \therefore-501 \\
& \text { ty } 4 x-5
\end{aligned}
$$

and

20

and (ए)

$6 y^{2}+2=200$

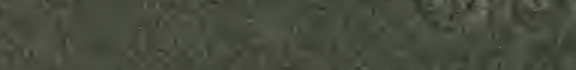

$y+z=0 y-2 y$

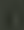




\section{ESTABLISHED 1872.}

To My Friends and Patrons:

Again I have the pleasure of greeting my many customers through the medium of my Seed Book for 1911, and wish to thank you for your liberal patronage in the past.

The rapid growth of my business each year is conclusive evidence that my seeds are giving satisfaction, that the care I exercise to guide the beginner in the selection of the proper varieties suited to the soil, the season, and to purpose for which each crop is intended, all prove my sincerity of purpose to help the grower to succeed.

It is needless for me to talk quality to those who have already purchased from me, nevertheless to the many who have not used my seeds, I wish to emphasize the fact, that I hold quality paramount in every sale I make.

Peas, beet and musk melon seeds are very short crop, and would advise my customers to order early of these.

Below I outline a few valuable hints on ordering seeds, which, if carefully followed, will facilitate immediate shipment. 1221 Washington Ave. North.

W. H. BOFFERDING.

\section{HOW TO ORDER SEEDS.}

Accompanying each catalog you will find order blanks and envelopes. Use the order blanks for orders only and follow instructions carefully-all additional information or questions should be written on a separate sheet. Be very explicit in giving name, full address and other shipping directions. Send cash with your order. You can send it by Post Office Money Order, Express Order, Bank Draft, Registered Letter, all of which I will be responsible for. Stamps will be taken as cash when received in good condition. No C. O. D. orders filled.

\section{POSTAGE RATES.}

Seeds in quantities of $1 / 4 \mathrm{lb}$. or less will be mailed post paid at list prices. Quantities of $1 / 2 \mathrm{lb}$. or over will require postage at the rate of $8 \mathrm{c}$ per 1b. in addition to catalog prices. Peas and Beans "require 15 , cents per qt: in addition to catalog prices.

Half lbs. are supplied at pound rates, half pecks at peck rates, $1 / 2$ bushels at bushel rates. No charge for boxes, bags or barrels.

\section{SHIPMENT.}

All orders are filled immediately upon receipt of same: If not. I notify you by return mail as to the reason.

If goods, notice of shipment or acknowledgment of order are not received within a reasonable time, it may be assumed that the order has been miscarried or the name and address, omitted. In such case notify me at once, giving your name and addriss and the list of some goods ordered so I will be able to check it up correctly and speedily. 


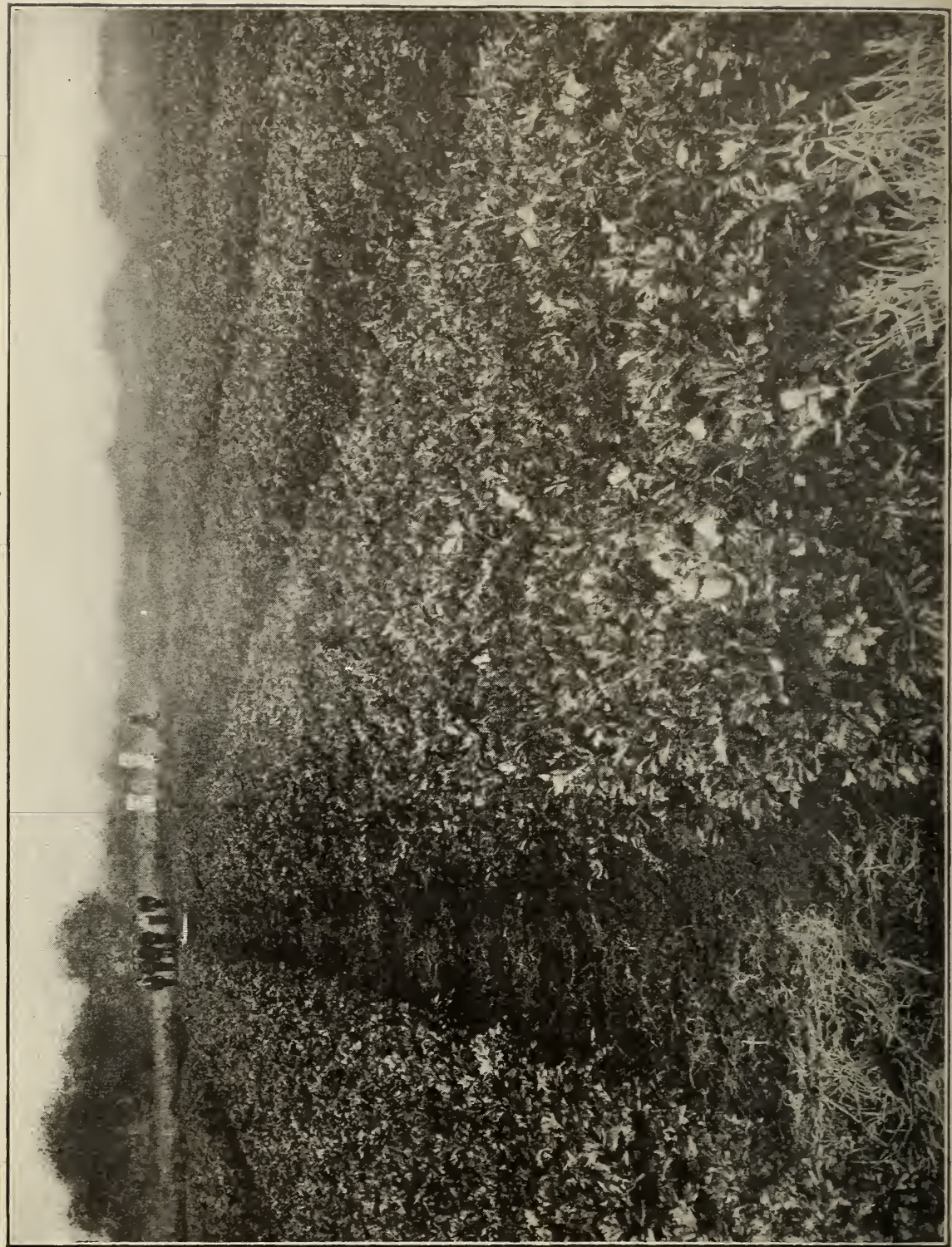

\section{CELERY-GOLDEN YELLOW, SELF BLANCHING. GROWN IN FRANCE}

This is the best celery for early use. It is in condition as early in the fall as any and we have yet to find an extra early sort equal in quality and appearance to my stock of Golden Yellow, Self Blanching. Critical gard. eners generally depend upon my stock to produce my finest early celery. Plants of a yellowish green color, but as they mature the inner stems and leaves turn a beautiful golden yellow so that blanching is effected at a minimum experdifure on timp ard tabor. The handsomest colof. efispress, tenderness, freedom from stringiness, and fine nutty flavor of this variety have fully established it as the standard first early sort.

Pkt. 10c; Oz. 60c; 1.4 lb. $\$ 2.00$ 
W. H. BOFFERDING, MINNEAPOLIS, MINN.

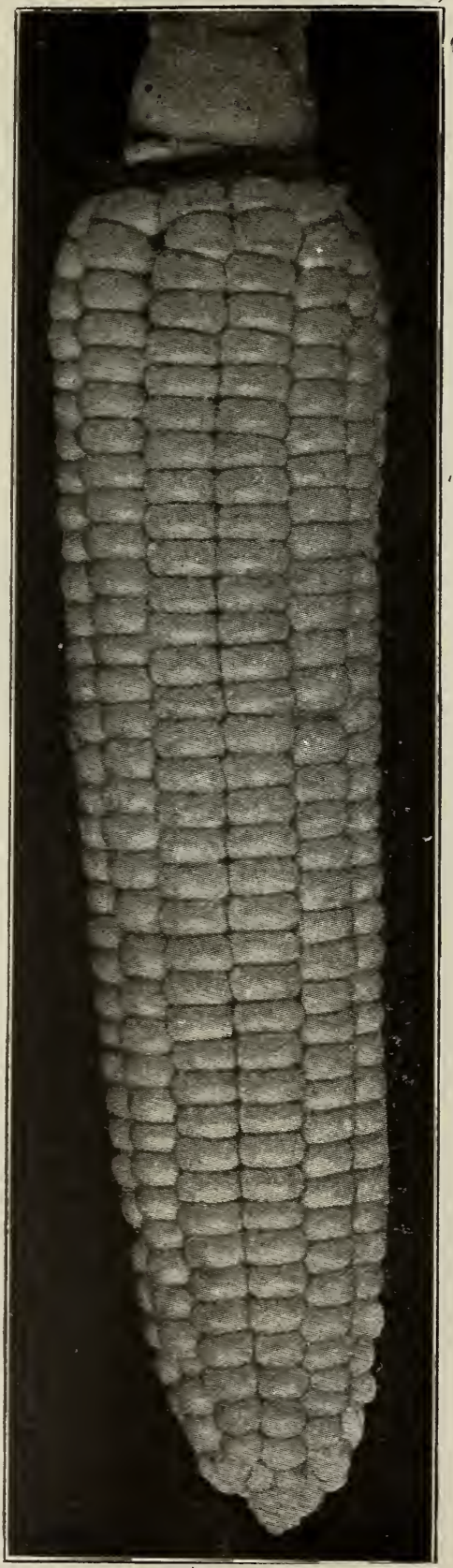

\section{SWEET CORN- \\ GOLDEN BANTAM, EARLY}

A new variety of sweet corn which many people consider the richest and sweetest of all corns. Some of my customers are now planting this corn at regular intervals during the season, so they may have it for table use continwally and prefer it to all other sorts. It may be planted thickly and as late as July 17 th. The corn itself is of a golden yellow color which at first gives one an impression of field corn, however, as soon as tasted there is an immediate call for more. My seed is raised from the originator's stock and has been selected specially for table quality. Pkt. 10c; Pt. 15c (by maii 20c); Qt. 30c (by mail 40c); by express2 Qts. 50c; Peck $\$ 1.60$.

Black Mexican.-This corn when in condition for the table, cooks remarkably white, but the ripe grain is black or bluish black. It is surpassed by none in tenderness and fine quality for family use. I consider it the most desirable second early sort. Stalks about six feet high. Pkt. 10c; Pt. 15c (by mail 20c); Qt. 30c (by mail 40c); by express-2 Qts. 50c; Peck $\$ 1.50$. 


\section{BEET-DETROIT DARK}

RED TURNIP.

Careful comparisons with all the prominent varieties on the market in this country and in Europe prove that the Detroit Dark Red Turnip Beet is the most uniform in shape and size and the most attractive in color. It is unsurpassed in quality. Universally recognized as the best beet for the market, the home garden and for canning. Pkt. $5 \mathrm{c} ; \mathrm{Oz} .10 \mathrm{c} ; \mathrm{r} / 4$ Lb. 25c; Lb. 75 c.

\section{CAULIFLOWER.}

No. 473 Danish-My own importation, seed grown by

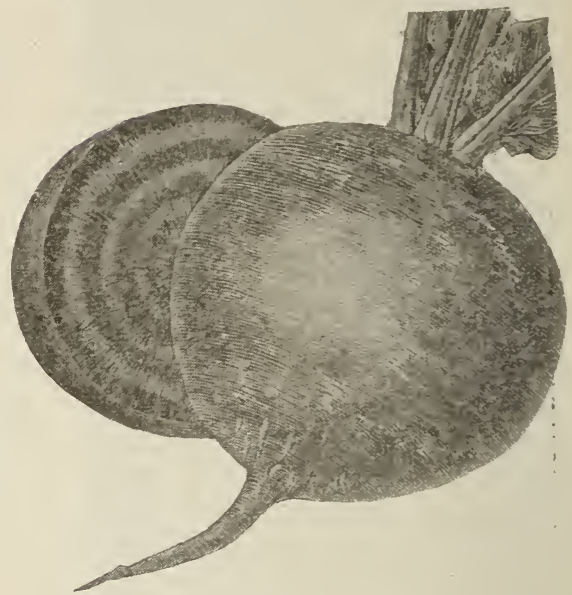

Detroit Dark Red Turnip one of the foremost growers of cauliflower seed in Denmark, a specialist in his line.

With proper soil and cultivation this is sure to produce uniform large white heads, a reliable sort, one can trust to make good. Pkt. Pkt. 10 c; $1 / 4$ Oz. $65 \mathrm{c} ;$ Oz. $\$ 2.25 ; 2$ Oz. $\$ 4.25 ; \mathrm{I} / 4$ Lb. $\$ 8.00$.

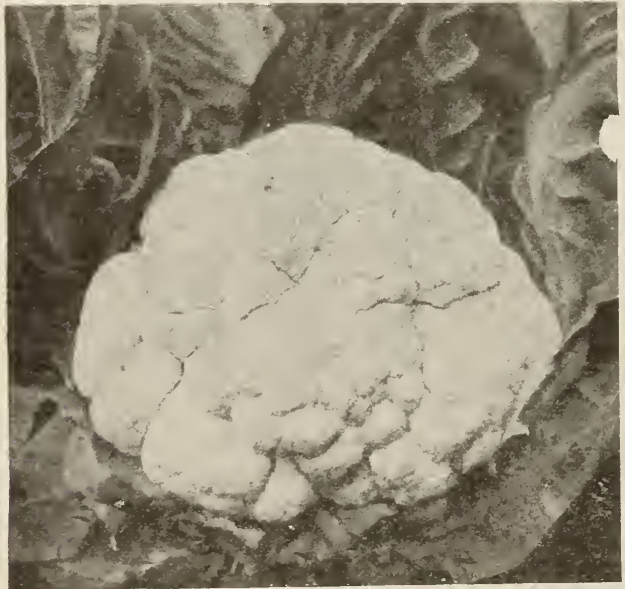

Early Snowball-Admirably adaped for forcing or wintering over for early crop and the most popular sort for these purposes. It is also one of the best sorts for late summer and fall crop and with reasonably favorable conditions every plant will form large. solid head of fine auality. The plants are compact, with few narrow, upright leares and are well silited for close planting. The heads are solid, compact, -ound, very white and curd like and are developed earlier than those of any other sort. I1 my recent comparative trials of samples from the best known growers and prominent seedsmen in Europe and America my stock of Early Snowball were unsurpassed by any in earliness. They also give the largest percentage of well formed heads. I am in position to supply the most critical trade with seed which can be depended upon as the very best. Pkt. 10 c; r $/ 4$ Oz. 65 c; Oz. $\$ 2.25 ; 2$ Oz. $\$ 4.25 ; \mathrm{I} / 4 \mathrm{Lb} . \$ 8.00$.

No. 888.-Most desirable for forcing and for first planting in the open ground. This is a thoroughbred strain of this popular variety. It is a trifle earlier than Snowball and dwarfer, otherwise quite similar. 
This seed will produce cauliflower the equal of any on the market. Good strains of this seed have a 50 to 60 year pedigree. They are so high bred that it is very seldom that the plants average good seed crop, hence the best seed is always dear and scarce. My seed is from a famous grower whose strain is unexcelled. Pkt. 25c; r/4 Oz. 75c; Oz. $\$ 2.50 ; 2$ Oz. $\$ 4.50$.

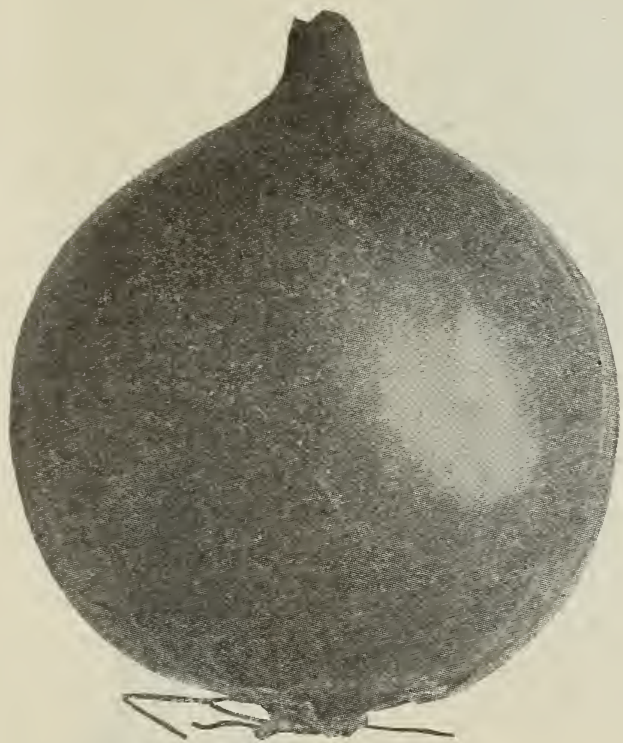

SELECT RED GLOBE

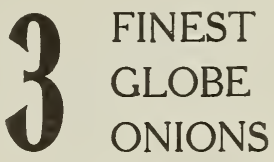

\section{GLOBE ONIONS.}

Different markets and localities prefer different onions. Globe Onions are generally most popular and yield better than the other sorts. Flat onions are the earliest and the large sized kinds have the best flavor. My Select White, Red and Yellow Globe are ideal of their kind and the most critical planters can rely upon this seed. Every bag of seed is tested as to vitality.

\section{SELECT WHITE GLOBE.}

This is the handsomest of all Onions. My genuine Eastern grown stock is of the true globe form; pure white, hard. small necked, ripening very early and evenly, a good keeper. I supply the largest market gardeners. To get a very fine white onion, pull just as they begin to go down, and dry in any airy and shady place. No market gardener or onion grower can afford to plant inferior seed, with only cheapness of price to recommend it, when seed like this is to be had, the results of a few ounces often paying twice the first cost of the best seed. Oz. $25 \mathrm{c} ; 2 \mathrm{Oz} .45 \mathrm{c} ; \mathrm{I} / 4 \mathrm{Lb} .80 \mathrm{c} ; \mathrm{Lb} . \$ 3.00$.

Select Southport Red Globe.-My Select Red Globe is a beautiful crimson red and a better lot of seed cannot be found. It is of immense size, very solid and firm-qualities which make it a fine seller and an excellent keeper. Our market garden customers regularly grow crops yielding 800 to 1,000 bu. from this seed. Our grower is an expert who especially selects this seed from large fine colored, solid bulbs, well cured and ripened, carefully avoiding all thick necked ones. Pkt. 10c; Oz. 20c; 2 Oz. 35c; r/4 Lb. 50c; Lb. \$1.75.

Select Southport Yellow Globe.-A main crop, late, large, round Onion. It is sure to satisfy the one who buys a packet or the one who sows 50 pounds for carload shipments. A truly grand Onion, whose large golden-yellow spheres make a beautiful appearance, sacked or barreled for the market. Finest of all yellow onions for keeping. My Eastern strain of seed is from a grower of twenty-five years' experience who makes a specialty of this variety. There is no better. Oz. 20c; 2 Oz. 35c; $1 / 4$ Lb. 50c; Lb. $\$ 1.75$. 


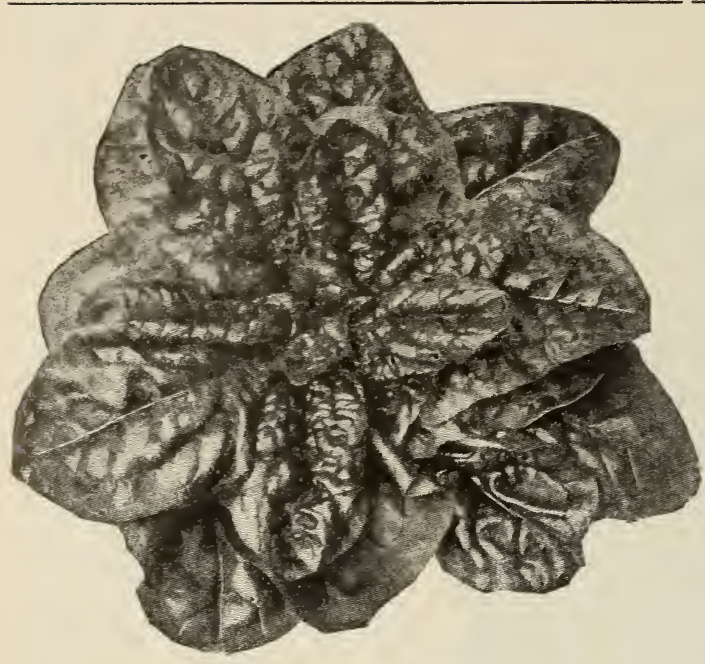

W. H. B. TRIUMPH

\section{RADISH-W. H. B. SELECT ICICLE.}

I have a special strain of this popular Radish that is in a class by itself. Everyone who plants radishes should put in a plat of this variety. Of highest quality and stays in an edible condition longer than any other early sort. Roots long, slender and white. Pkt. 5c; Oz. 10c; r/4 Lb. 20c; Lb. 65c.

\section{RADISH.}

Improved Early Scarlet Globe.-W. H. B. Selected Stock.-A most desirable sort for greenhouse and hot-bed forcing and for outof-doors; very early, mild, crisp, juicy and tender: top small and will stand heat without becoming pithy. One of the best selling and most attractive radishes on account of its handsome rich bright scarlet color. Is ready in 25 days. My stock of this is the very best. selected with care as to size, shape, color and earliness, and market gardeners will find it a money maker; it is just right in every respect. We take great pains to have it so and our gardener customers who plant this seed always command the highest market prices. For family use this should be sown every ten days in order to always have a fresh supply. Pkt. 5c; Oz. 10c; x/4 Lb. 20c; Lb. 70c; by express -5 Lbs. $\$ 3.25 ; 10$ Lbs. $\$ 6.00$.

\section{SPINACH.}

W. H. B. TriumphIn this new Spinach we have a large growing variety of the best quality that withstands hot weather longer than any other sort. By its use the Spinach season may be lengthened a whole month. We anticipate great popularity for it as it is not only long standing, but is also superior in quality and size to all the older kinds. Pkt. 5c; $2 \mathrm{Oz}$. 10c; $1 / 4 \mathrm{Lb}$. $15 \mathrm{c}$; Lb. $25 \mathrm{c}$.

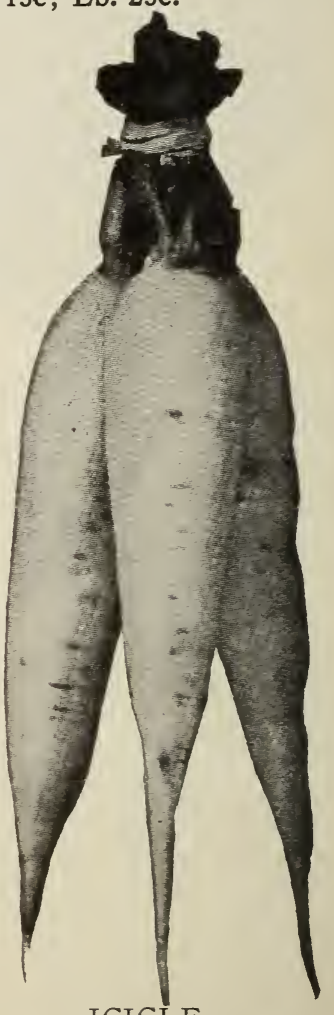


BUSH BEANS.

New Kidney Wax.

Every grower should try this splendid new bean. Robust in growth, plants about 18 to 20 inches high, more prolific than the Wardwell's Kidney Wax, longer pods, handsomer in appearance, entirely stringless, fleshy, and of fine quality.

This is the best bean I ever saw, my grower mailed me samples which were long, well shaped and brittle, he claims this is more productive than any of the older sorts.

Plants erect bush habit, foliage free from blight, while the pods are free from rust so common with most the other varieties.

The season for bearing is the same as Wardwell's Kidney Wax. Packet, 10c; Pint, 25c; Qt., 40c; Peck, $\$ 2.25$.

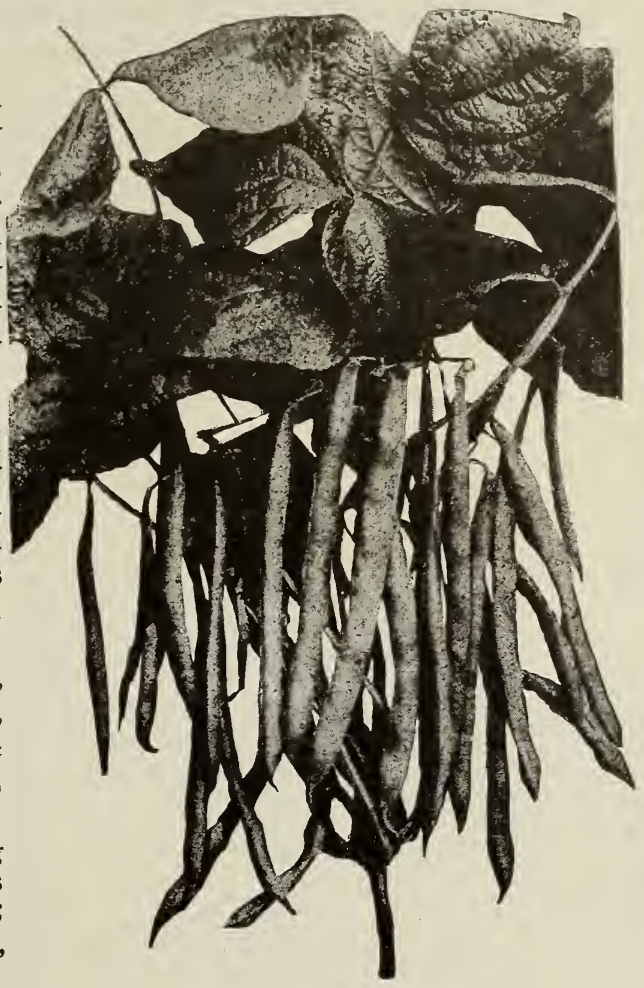

\section{PEAS-ALDERMAN.}

In many respects the very best early main crop pea of the valuable Telephone type. Pods very large, long, dark green, similar to Duke of Albany and about the same in season; peas of largest size and unsurpassed in quality. Market gardeners are demanding the large podded, dark colored sorts which retain their fine appearance even after shipping a long distance. The Alderman answers these requirements and furthermore is the most productive variety of this class. Pkt. 10c; Qt. 40c; I $/ 4$ Bu. $\$ 3.25 ;$ Bu. $\$ 11.50$.

\section{CABBAGE-HOLLANDER OR DANISH BALL HEAD.}

Very hardy. handsome, very solid, of fine quality and as one of the very best keepers it is particularly desirable for distant markets or for late spring use. Plant vigorous, compact growing, with longer stem than most American sorts and exceedingly hardy in resisting cold and dry weather; leaves large, thick, bluish green covered with whitish bloom. Head medium sized, round, very solid and stands shipment better than any other late sort. I offer seed of my own contract growing which, judging from recent trials, will produce more uniformly typical heads than can be grown from the best stocks obtainable elsewhere. Pkt. 5c; Oz. 30c; 2 Oz. 55c; $1 / 4$ Lb. $\$ 1.00 ; \mathrm{Lb}$. \$3.50. French grown. 


\section{SPECIAL PRICE LIST OF BOFFERDING'S TESTED AND TRUE GARDEN AND FLOWER SEEDS.}

My prices are based on customer paying transportation charges, but when Packets, Ounces and Quarter Pounds are wanted by mail I pay the postage. When larger lots, such as Pounds or Quarts, are wanted by mail or express, prepaid, customer must remit 8 cents per pound and 15 cents per quart extra.

When not ordered by mail or express, prepaid, as above described, I will ship by freight or express at buyer's expense.

All packets of vegetable seeds 5 cents unless otherwise noted.

ASPARAGUS.

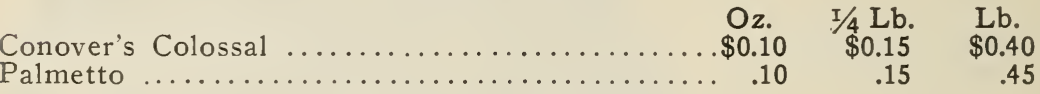

ASPARAGUS ROOTS.

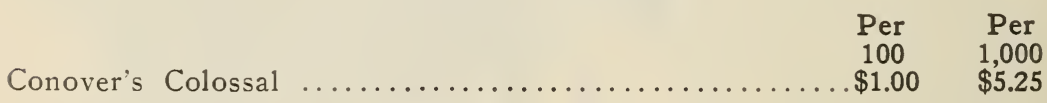

\section{BEANS-DWARF.}

Triumph, New Kidney Wax......... $\$ 0.4$

Challenge Dwarf Black Wax, 35 days.... .30

Golden Wax, 35 days................. .30

Refugee Wax, 40 days................30

Wardwell's Kidney Wax, 45 days....... .30

Davis Wax, 45 days.......................

Extra Early Refugee, 30 days.......... .25

Early Mohawk, 38 days................25

Dwarf Horticultural (Cranberry)......... .30

Refugee or 1000 to One, 40 days....... .25

Dwarf Large White Lima.............. .40

Burpee's Improved Bush Lima......... .40

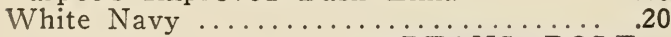

BEANS-POLE.

Kentucky Wonder or Old Homestead.... .40

2 Qts.

$\$ 0.75$

.50

.50

.55

.55

.55

.45

.45

.55

.50

.75

.75

.35

.75
Peck.

$\$ 2.25$

1.75

1.75

1.75

1.75

1.75

1.50

1.45

1.75

1.50

2.50

2.50

1.00

2.00

Beans, pkt. 10c, postpaid.

\section{BEET.}

Extra Early Egyptian Blood Turnip, 40 days..... $\$ 0.10$

Crosby's Egyptian, Early, 45 days................ .10

Detroit Dark Red Turnip (5 lbs. \$3.50), 48 days.. .10

Crimson Globe ........................ 10

Early Eclipse, 40 days..................... .10

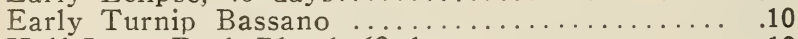

Half Long Dark Blood, 62 days...................

Swiss Chard or Sea Kale Beet.

.10

$1 / 4 \mathrm{Lb}$. $\$ 0.20$

.20

.25

.20

.15

.15

.15

.15
$\mathrm{Bu}$.

-...

$\cdots \cdots$

6.75

6.50

6.50

5.25

5.00

5.50

.....

4.00

\section{BEET FOR STOCK FEEDING.}

Giant Feeding Sugar Beet, Half Sugar Mangel, $95^{1 / 4}$ days

$\mathrm{I} / 4 \mathrm{Lb}$

$1 \mathrm{Lb}$.

5 Lbs.

Improved Long Red, 120 days.

Golden Tankard, 100 days................... . .10

Rose Leaf Sugar Beet Mangel................. .10

$\$ 0.30 \quad \$ 1.25$

$.30 \quad 1.35$

$.35 \quad 1.55$

$.30 \quad 1.40$ 
BRUSSELS SPROUTS.

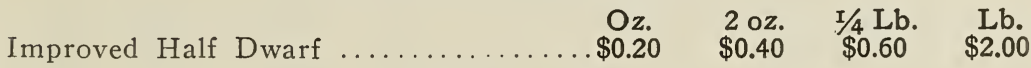

\section{CABBAGE.}

Early Jersey Wakefield, 75 days...... $\$ 0.30$

Charleston or Large Wakefield, about 80 days ........................ .30

Henderson's Early Summer, 80 days..... .20

Early Dwarf Flat Dutch, 80 days....... .20

All Seasons, 90 days..................20

Succession, 90 days ...................25

All Head Early, or Faultless.......... .25

$\$ 0.55 \$ 0.85 \quad \$ 3.00$

$\begin{array}{lll}.55 & .85 & 3.00\end{array}$

$\begin{array}{lll}.35 & .60 & 2.50\end{array}$

$\begin{array}{lll}.35 & .60 & 2.25\end{array}$

$\begin{array}{lll}.35 & .60 & 2.50\end{array}$

$\begin{array}{lll}.45 & .75 & 2.50\end{array}$

$\begin{array}{lll}.45 & .85 & 3.00\end{array}$

Late or Autumn and Winter Sorts.

The Warren or Improved Stone Mason.. .25

Surehead ......................... $\quad .20$

Premium Flat Dutch ............... .20

Premium Drumhead .................. .20

Hollander or Danish Ballhead.............30

Danish Ballhead, long stem, fine keeper.. .30

Longkeeping, one of the best for storing .30

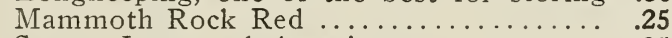

Savoy, Improved American........... .25

\section{CARROTS.}

Three Ounces of Seed to 100 Yards of Row. 60 to 70 Days from Germination to Maturity For Table.

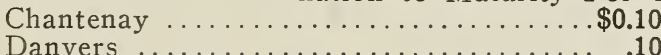

Guerande or Ox Heart................ .10

Improved Short White.............. 10
$\$ 0.15$

.15

.15

.15
$\$ 0.25$

.25

.20

.20
$\$ 0.75$

.85

.70

.60

\section{CAULIFLOWER.}

One-half Ounce of Seed to 100 Yards of Row.

Pkt. Oz. 2 oz.

Danish No. 473, The Prize Winner..... \$0.10
Early Snowball, 90 to 100 days....... 10

No. 888, 90 to 100 days............... .25

Early Favorite
$\$ 2.25$

2.25

2.50

.75
$\$ 4.25$

4.25

4.50

1.25
$\mathrm{T} / \mathrm{L} \mathrm{Lb}$. $\$ 8.00$ 8.00 8.50 2.00

\section{CELERY.}

Golden Yellow Self Blanching.........\$0.10 White Plume .05 $\$ 0.60$ $\$ 1.10$ $\$ 2.00$ $.20 \quad .35$

CHERVIL.

Curled

$\mathrm{O} z$.

$\$ 0.15$

CHICORY.

Large Rooted $\$ 0.15$

CORN SALAD.

Large Seeded $\$ 0.10$ CRESS.

Lb. 
70 to 90 Days.

Premo Extra Early

Mammoth White Cory

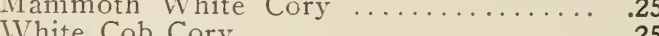

Crosby's Early

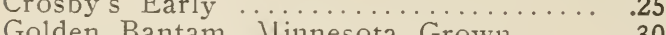

Perry's Hybrid

Black Mexican

Early Evergreen

Country Gentleman

Stowell's Evergreen

Zig Zag Evergreen Corn, Minnesota Grown, fine strain, one of the very

Corn Pkt. 10c Postpaid.

CUCUMBER.

Extra Long, or Evergreen White Spine... .10

Muscatine Pickling .................. .10

Boston Pickling ..................... .10

Chicago Pickling ................. .10

Jersey Pickling ................... .10

Improved Long Green, Superior Stock... .10

DANDELION.

Improved Thick Leaved, Pkt. 10c......\$ \$0.40

EGG PLANT.

Improved Large Purple Spineless.......\$0.35

ENDIVE.

Large Green Curled................\$0.15

Moss Curled .............................

Broad Leaved Batarian...................

Louvier's Laciniated New ........... .20

KALE OR BORECOLE.

Tall Green Curled Scotch..............\$0.10

Dwarf Curled Scotch, or German Greens .10

KOHL RABI.

Early White Vienna, for forcing........\$0.20

Large Green ...................... .15

LEEK.

Large American Flag ..............\$0.10
Early Bantan, Minnesota Grown...... .30

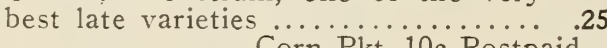

Davis Perfect, fine strain for forcing....\$0.15

2 Qt.

$\$ 0.45$

.45

.45

.45

.50

.45

.45

.50

.45

.45

.45

.45

1.25

4.50

$2 \circ \mathrm{oz}$

$\$ 0.30$

.20

.20

.20

.20

.20

.20

$\$ 0.75 \$ 1.30$

$\$ 0.60 \$ 1.10$

$\$ 0.25 \$ 0.40$

$.25 \quad .40$

$.25 \quad .40$

$.35 \quad .60$

$\$ 0.15 \$ 0.20$

$.15 \quad .20$

$\$ 0.60$

.60

$\$ 0.35 \$ 0.60$

$.30 \quad .50$

$\$ 0.20 \quad \$ 0.30$

$\$ 1.10$

LETTUCE-HEAD OR CABBAGE.

May King ....................... $\$$

Market Gardeners Private Stock....... .10

Iceberg ............................ .10

Golden Yellow Stonehead ............. .10

Unrivaled. Improved Big Boston......... .15

Mammoth Black Seed Butter............... 10

Big Boston

.15
$\$ 0.25$

.15

.20

.20

.25

.15

.25
$\$ 0.40$

.30

.35

.35

.40

.30

.40
$\$ 5.00$

5.00

4.75

4.50

6.00

4.75

4.75

5.50

5.00

5.00

4.00

Lb.

$\$ 1.75$

1.00

1.15

.90

.90

.90

1.25
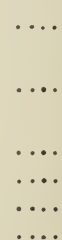

LETTUCE-CURLED OR LOOSE LEAVED.

Grand Rapids, for forcing.........\$0.10

Ferry's Early Prize Head.............. .10

Black Seeded Simpson ................... .10
$\$ 0.20 \$ 0.30$

.15

.15
$\$ 1.50$

1.00

1.25

1.25

1.50

1.00

1.50 


\section{MUSK MELON-GREEN FLESHED.}

$\mathrm{Oz} . \quad 2 \mathrm{Oz}$

Extra Early Citron.................\$0.10

Extra Early Hackensack ............. .15

Rocky Ford ...................... .10

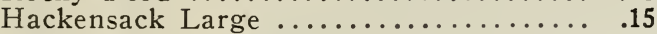

Tip Top ............................ .10

Yellow Fleshed Varieties-

Osage ............................10

Surprise ....................... 10

White Japan ......................15

WATER MELON.

Kleckly's Sweets, one of the sweetest... \$0.10

Round Light Icing................. .10

Tom Watson New .................. .10

Dark Icing, Early .................. .10

Sweet Heart .................... .10

Citron, for preserving, pink seed....... .10

NASTURTIUM.

Tall Mixed Garden ................ \$0.10

Lb.

$\$ 0.20 \$ 0.30$

$\$ 1.00$

.20

.15

.35

1.00

.25

.20

.20

1.00

1.25

1.25

$.20 \quad .35$

1.25

$.20 \quad .35 \quad 1.10$

$.25 \quad .45 \cdot 1.50$

$\$ 0.20 \quad \$ 0.25 \quad \$ 0.85$

$\begin{array}{lll}.15 & .25 & .75\end{array}$

$\begin{array}{lll}.20 & .30 & 1.00\end{array}$

$\begin{array}{lll}.15 & .25 & .75\end{array}$

$\begin{array}{lll}.15 & .25 & .75\end{array}$

$\begin{array}{lll}.15 & .25 & .85\end{array}$

OKRA OR GUMBO.

White Velvet $\$ 0.10$

ONION.

Extra Early Red .................. \$0.20

Large Red Wethersfield .............. .20

Southport Red Globe................ .20

Southport Red Globe, Selected Stock.... . .20

Michigan Yellow Globe.............. .20

Southport Yellow Globe, Selected Stock.. $\quad .20$

Southport White Globe, Selected Stock.. .25

Mammoth Yellow Spanish or Prizetaker.. $\quad .20$

White Portugal, for sets.............. .25

Queen, for pickling ................15

$\$ 0.15 \$ 0.20$

$\$ 0.10 \quad \$ 0.15 \quad \$ 0.45$

$\$ 0.30 \quad \$ 0.50 \quad \$ 1.65$

.30

.30

.35

.35

.35

.45

.35

.45

.25

.55
.45
.50
.60
.50
.80
.50
.75
.45

2.00

1.50

1.75

1.90

1.75

3.00

1.75

2.75

1.60

ONION SETS.

Red Bottom ............................ Ler $\$ 0.20 ; 100$ Lbs. $\$ 10.00$

Yellow Bottom Sets ...................Per Lb. $.20 ; 100$ Lbs. 10.00

White Bottom Sets ..................Per Lb. .20; 100 Lbs. 10.00

The single pound price will hold good during the season, or as long as stock lasts. Prices by the $100 \mathrm{lbs}$. of all sets are subject to fluctuations of the market. Write for prices.

PARSLEY.

$\mathrm{Oz}$. $\$ 0.10$

Plain

Champion Moss Curled

Turnip Rooted or Hamburg

\section{PARSNIP.}

.10

.10
2 oz. $\$ 0.10$

.10

.10

$\mathrm{Oz}$.

$\$ 0.10$
$1 / 4 \mathrm{Lb}$. $\$ 0.15$ .15 .15

Lb. $\$ 0.45$ .55 .45

$\mathrm{I} / 4 \mathrm{Lb}$. $\$ 0.15$
Lb. $\$ 0.50$

\section{PEPPER.}

Red Cherry ..................

Red Chili .....................25

Long Red Cayenne................. .25

Large Bell or Bull Nose............ .20

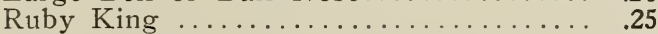

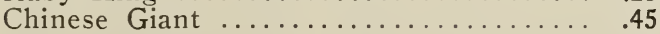

Improved Thick Long Red ............ . 30

2 oz. $\$ 0.45$ 
Extra Early Sorts-

PEAS.

Ferry's First and Best.

Alaska or Earliest of All

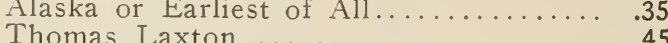

Gramas Laxton ....................... .45

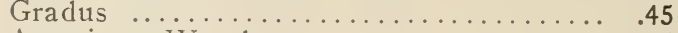

American Wonder .................. .35

Nott's Excelsior ..................... .40

Second Early-

Telephone

$\$ 0.45$

Alderman

.45

Melting Sugar

.40

Peas, Pkt., 10c Postpaid.

Field Sorts-

Choice White

\section{PUMPKIN.}

$\$ 0.10$

Large Yellow

Sugar or New England Pie...

.10

RADISH.

Prussian Globe, Deep Scarlet Turnip

Forcing .................. \$0.10

Early Scarlet Globe, Improved Select

$$
\text { Stock }
$$

Vick's Scarlet Globe

Crimson Giant, French Grown......... .10

Early Long Scarlet, Short Top......... .10

Special, Half White, Scarlet Turnip..... .10

French Breakfast .................. 10

Crimson Giant, California Grown........ .10

Wood's Early Frame ................ . 10

Improved Chartier or Shepherd........... .10

Early Golden Yellow Oval............ 10

Long White Vienna or Lady Finger.... . 10

Icicle, fine crisp, the best long white..... .10

Early White Giant Stuttgart .......... .10

White Strasburg

WINTER VARIETIES.

Scarlet China ...................\$0.10

California Mammoth-White China ..... .10

Round Black Spanish ................ 10

Long Black Spanish ................ .10

RAPE.

Lb. $10 \mathrm{Lbs}$.

$\$ 0.15$

.15

.15

.15

$\$ 0.15$

Dwarf Essex, for sowing.............. $\$$
RHUBARB.

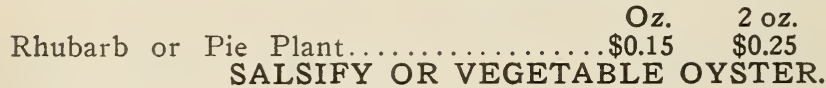

Mammoth Sandwich Island............\$0.15 \$0.25

$\$ 1.15$

.15
$\mathrm{I} / 4 \mathrm{Bu}$.

$\$ 2.20$

2.25

$80 \quad 3.20$

$.80 \quad 3.20$

$.70 \quad 2.35$

$.75 \quad 2.50$

9.50

$\$ 0.85 \$ 3.00$

$\$ 11.00$

3.25

11.50

$\$ 8.50$

12.50

12.50

$\ldots .50$

.....

Market Price.

$2 \mathrm{oz} . \quad \mathrm{I} / 4 \mathrm{Lb}$.

Lb.

$\$ 0.10 \quad \$ 0.30$

.60

$\$ 0.15 \$ 0.20 \quad \$ 0.60$

.20

.70

$.20 \quad .60$

$.25 \quad .85$

$.15 \quad .55$

$.25 \quad .75$

$.20 \quad .60$

$.20 \quad .55$

$.15 \quad .50$

$.20 \quad .60$

$.25 \quad .65$

$.20 \quad .60$

$.20 \quad .65$

$.20 \quad .60$

$.20 \quad .60$

$\begin{array}{rr}\$ 0.20 & \$ 0.60 \\ .25 & .70 \\ .20 & .60 \\ .20 & .55\end{array}$

100 Lbs. Mkt. Price. SPINAGE.

$\mathrm{I} / 4 \mathrm{Lb}$.

Bloomsdale, Landreth's .............\$0.10

Savoy Leaved ...................... .10

Triumph or Long Season............. .10

Round Summer Broad Leaf............ .10

Long Standing ................... $\quad .10$

$1 \mathrm{Lb}$.

$\$ 0.25$

.20

.25

.20

$\mathrm{T} / 4 \mathrm{Lb}$.

$\$ 0.35$

Lb.

$\$ 1.10$

$\$ 0.35$

$\$ 1.25$

Long Standing Prickly............... .10

10 Lbs. 25 Lbs.

$\$ 2.25$

1.75

$\$ 3.75$

2.25

5.00

1.75

3.75

1.75

3.75

2.00

4.00 


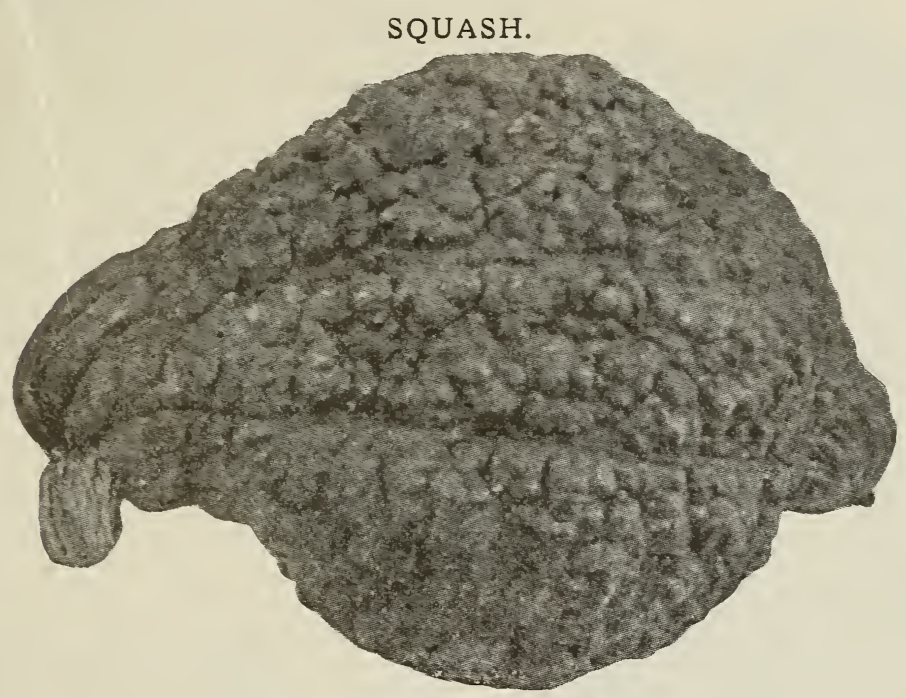

The Perry Hubbard Squash

\begin{tabular}{|c|c|c|c|c|}
\hline e Bush S & $\begin{array}{r}\mathrm{O} z \\
\$ 0.10\end{array}$ & $\begin{array}{l}2 \mathrm{oz} . \\
\$ 0.15\end{array}$ & $\begin{array}{l}T / 4 \mathrm{Lb} . \\
\$ 0.30\end{array}$ & $\begin{array}{l}\text { Lb. } \\
\$ 1.00\end{array}$ \\
\hline moth Summer Crookneck. &.$\quad .10$ & .15 & .30 & 1.00 \\
\hline hook $\ldots \ldots \ldots \ldots \ldots$. & .1 & .15 & .20 & .70 \\
\hline cious & .10 & .1 & .25 & .85 \\
\hline bbard, the P & .10 & .1 & .25 & .75 \\
\hline mmoth Chili & .10 & .20 & .35 & 1.25 \\
\hline
\end{tabular}

The Peary Strain Hubbard Squash is the result of careful selection, by one of the best known squash growers in this locality.

Large hard, dark green, heavily warted skin, thick fleshed and a heavy cropper. A favorite with the marketmen and shippers.

\section{SUGAR CANE OR SORGHUM.}

Lb.

Early Amber ........................ $\$ 0.15$

For Fodder

SUNFLOWER.

Mammoth Russian

Lb. $\$ 0.10$
100 Lbs. Mkt. Price. Mkt. Price.

\section{TURNIP.}

Turnip, Extra Early White Milan...........\$0.10

Extra Early Purple Top Milan............... .10

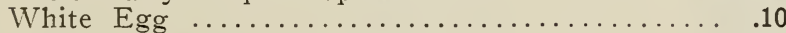

Early Purple Top, Strap Leaved............... .10

Purple Top, White Globe................... 10

Yellow Fleshed Turnips-

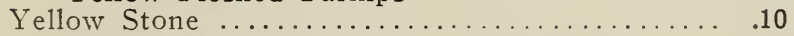

Rutabagas or Swedes-

American Purple Top ..........................

Sutton's Champion .............................

Bloomsdale, Swede

.10

10 Lbs.

$\$ 0.60$

z. I $1 / 4 \mathrm{Lb} . \quad \mathrm{Lb}$.

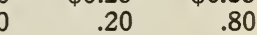

$\begin{array}{ll}.15 & .55\end{array}$

$\begin{array}{ll}.15 & .55\end{array}$

$\begin{array}{lll}0 & .15 & .50\end{array}$

$\begin{array}{ll}15 & .40\end{array}$

$.15 \quad .35$




\section{TOMATOES.}

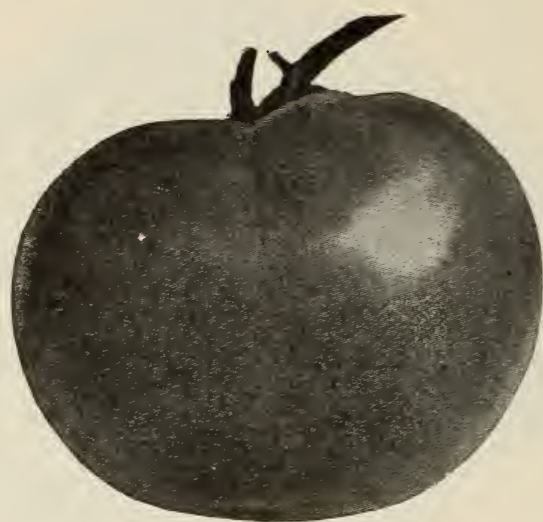

JUNE PINK

June Pink, Best Early Variety..............\$0.30

Oz.
$\$ 0.30$
.25

Stone, One of the Best Late................ .25

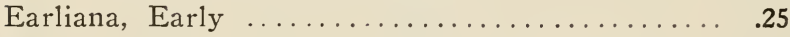

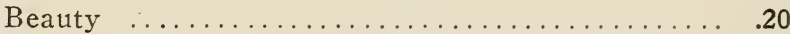

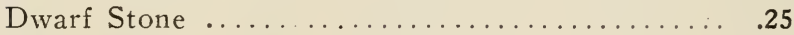

Acme .............................. .20

Livingston's Globe .................. $\quad .30$

Dwarf Champion, Improved............... $\quad .20$

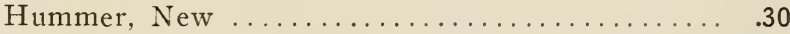

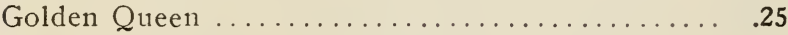

Peach .............................. .25

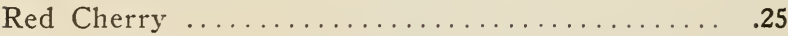

Yellow Plum ........................ ${ }^{25}$

Yellow Husk or Ground Cherry............. .25

2 oz. $\quad \mathrm{L} / 4 \mathrm{Lb}$. $\$ 0.55 \quad \$ 1.00$

$.35 \quad .65$

$.45 \quad .80$

$.35 \quad .65$

$.35 \quad .65$

$.35 \quad .65$

$.55 \quad 1.00$

$.40 \quad .75$

.45

.75

SWEET HERBS.

Sage, broad leaved

Pkt.

$\mathrm{Oz}$ .45 .70

Thyme $\$ 0.05$

Summer Savory

.10

Sweet Marj rram .05

Caraway

.05

Hoarhound

.05

Saffron

.05

$\$ 0.15$

.40

Coriander

.05

Sweet Basil

.05

I/4 Lb. Lb.

Lavender ......................... .05 


\section{QUALITY SEED CORN.}

The splendid varieties described and priced on this page are all grown in Hennepin and Brown Counties, carefully selected for seed. If you want seed corn that will mature in this northern latitude and produce a fine crop of large, fully developed ears, I don't hesitate in recommending the kinds listed. My aim is to have good corn to offer for seed, for cheap seed is too dear at any price.

Minnesota No. 13. This well known corn originated by Prof. Hays, of the Minnesota Experimental Station, is one of the earliest Yellow Dent varieties, this every corn grower will admit is the essential feature to be considered in buying corn for planting in the northern latitudes. The stock I offer is grown for me in Brown County. With good soil and proper cultivation you can't help having a well filled crib of good corn.

Price, Qt., postpaid, 30c. By express, Peck., 80c; Bu., \$3.00.

Dodd's Yellow Dent. I have sold Dodd's Yellow Dent corn for ten seasons, and can say truthfully, that I have yet to hear a single complaint from a customer not being satisfied with this corn.

I do not hesitate to recommend this to the most critical grower. In the summer of 1908 very little corn properly matured, the Dodds, however, thoroly ripened, which proves it to be next to flint in earliness.

Price, Qt., postpaid, 30c. By express, Peck., 80c; Bu., $\$ 3.00$.

Rustler White Dent. This splendid white corn is one of the main crops in this locality. Selected for earliness with fine formed large ears and deep kernel, tip and butt well rounded. Can't be beat.

Price, Qt., postpaid, 30c. By express, Peck., 80c; Bu., \$3.00.

Longfellow Flint. A prolific early 8-rowed yellow variety of

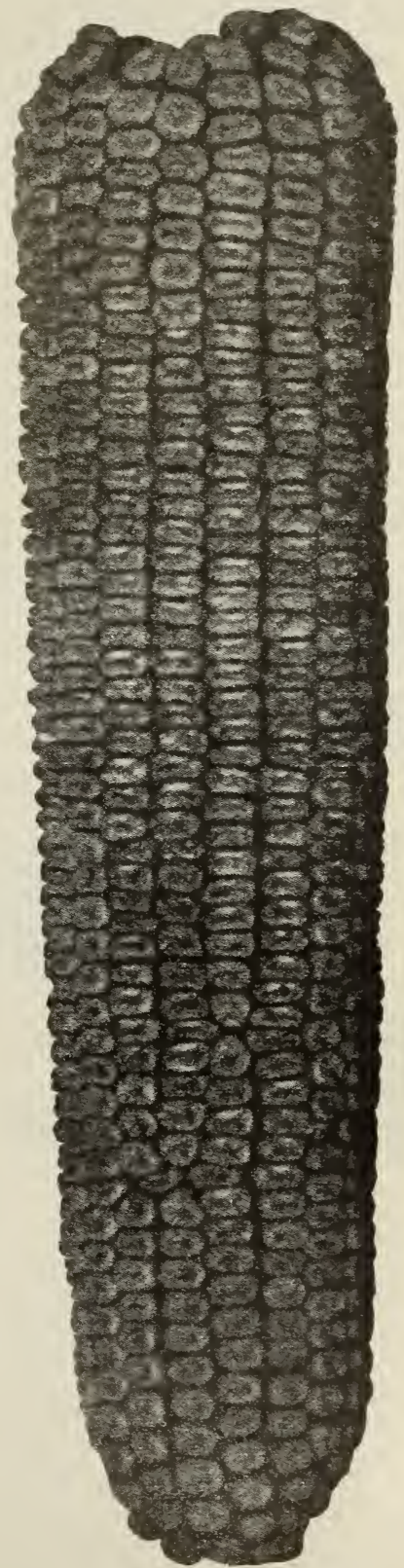

DODD'S YELLOW DENT 
very handsome appearance. The ears are close, with large broad kernels. Very desirable for the northwest. Price, Qt., postpaid, 35c. By express, Peck, 85c; Bu., $\$ 2.75$.

Red Cob Fodder Corn.-This variety is now grown in the large dairy regions of Minnesota so extensively as almost to exclude all the other so-called fodder corn, and the verdict is that it is the best. It is sweet, tender and juicy; has short joints, abundance of leaves, grows to great height, furnishing more than double the bulk and more nourishment than ordinary field corn. Thoroly tested and recleaned, hence you buy no cobs or dirt. Price, Peck, 40c; Bu., $\$ 1.25$. Write for prices in larger lots.

Sugar Cane for Fodder. Write for prices.

TRIUMPH CANADIAN OATS.

Ninety-one bushels of two and one-half bushels sowed is the results one of my customers reports of this wonderful oats.

Grown in the extreme north, large grain, thin hull, almost as heavy as wheat, stand up stiff and straight until fully matured.

Try this, you are in a way to increase your income when you use this oat. Price, Peck, 40c; Bu., $\$ 1.35 ; 2 \mathrm{I} / 2$ Bu., $\$ 2.25 ; 10$ Bu., $\$ 12.00$, bags included.

SWEDIS.H SELECT, Peck 40c; Bu. \$1.25.

PLANET, JR., GARDEN TOOLS.

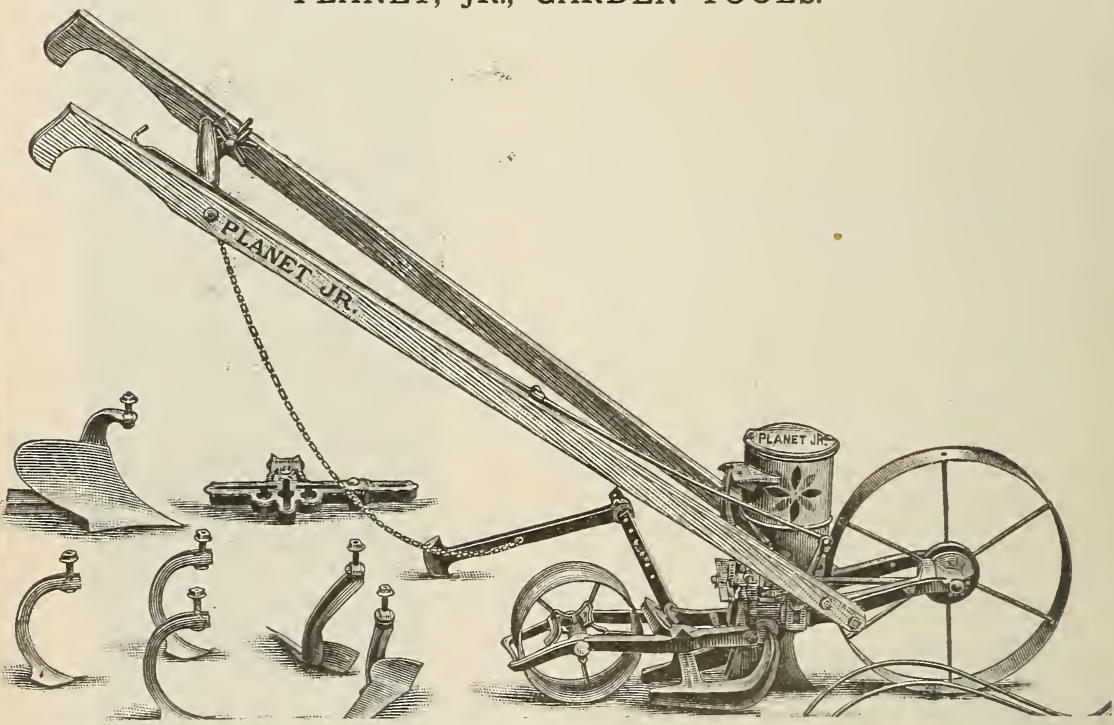

Delivered at Depot or Express Office Minneapolis, Minn., at List Price. Planet Jr. No. 6.-Price as a drill only, \$11.00; complete, Hill and Drill, Seeder and Wheel Hoe-Cultivator and Plow combined, \$13.50.

Planet Jr. No. 4.-Combined Hill and Drill Seeder, Wheel Hoe, Cultivator and Plow (no Rakes). Price, complete, $\$ 11.00$. Price, as a Drill only, $\$ 9.00$.

Planet Jr. No. 3.-Price as a Hill and Drill Seeder only, $\$ 10.50$.

Planet Jr. No. 13.-Double Wheel Hoe, with one pair hoes only, $\$ 4.75$.

Planet Jr. No. 13r $/ 2$. - Disc Hoe, $\$ 6.00$.

Planet Jr. No. 18. - Single Wheel Hoe. with one Dair hoes only. $\$ 3.50$. 


\section{ATTACHMENTS.}

These attachments will fit the Double and Single Wheel Hoes, except No. 19, and are sold separately if desired.

Discs, per pair, \$2.25.

Three-Prong Cultivator Teeth, per pair, \$1.30.

Plows, per pair, \$1.10.

C. \& D. Hoes, complete, $4 \mathrm{r} / 2$-inch, $80 \mathrm{c}$ per pair.

C. \& D. Hoes, complete, 6 -inch, $90 \mathrm{c}$ per pair.

C. \& D. Hoes, complete, 7 -inch, $\$ 1.00$ per pair.

C. \& D. Hoes, complete, 8 -inch $\$ 1.10$ per pair.

Onion Set Plow and Coverer, each, $\$ 1.00$.

Handles, per pair, 70c.

Excelsior Weeding Hook. Price, 20c, postpaid.

Steel Garden Trowels, 6-inch blade. Price, 25c, postpaid.

Hazeltine Hand Wheeler and Scraper. Price, 25c, postpaid.

Complete catalogue of Planet Jr. Garden Tools sent on request.

ESSEX-MODEL STANDARD INCUBATORS. 1911 Model.

The Famous Essex-Model "Standard" Incubators are acknowledged by

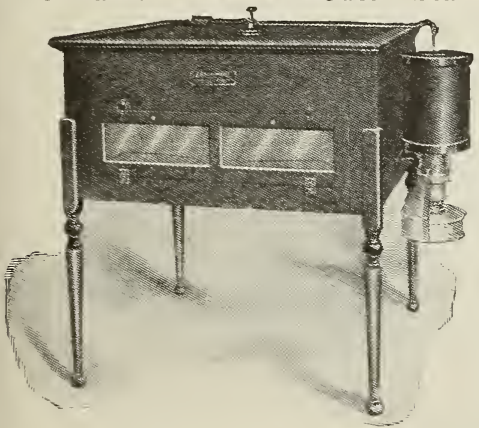
most successful poultrymen to be America's Leaders in Artificial Incubation. They are designed especially for people who not only want a good hatcher but a machine that in appearance will be a credit to their incubator cellars. Superiority appears in their every line.

These Standard Incubators are made of hardwood-high grade chestnut. They possess double walls, thoroughly insulated and packed. The tops also are packed with several thicknesses of laminated cotton batting; and the windows are of double

glass, with air space between.

The heater is of metal, covered with a thick corrugated asbestos jacket, having enameled metal rims.

The lamp rest is made of strap iron one inch wide, bolted to a heary galvanized iron shield and cone-shaped deflector that for safety, strength, and symmetry is unequalled.

The non-shrinkable metal regulator arm cann ot increase nor decrease in weight by the action of moisture or heat as wooden arms do, thereby making perfect regulation impossible.

A most important feature is the Essex Corrugated Thermostat-the heart of the machine. It is the most rigid, the most sensitive quick-acting Thermostat made. It is patented and therefore may be used only in the Essex-Model Incubators.

From erer point of view the Essex-Model Incubators are the best machine made, possessing strength, durability, finish, and hatchability.

\section{ESSEX-MODEL STANDARD INCUBATORS.}

No. 0 Standard Incubators; Holds 100 Eggs; Price, $\$ 17.00$.

No. 1 Standard Incubators; Holds 175 Eggs; Price, 23.00.

No. 2 Standard Incubators; Holds 275 Eggs; Price, 32.00.

No. 3 Standard Incubators; Holds 410 Eggs; Price, 37.00.

All Essex-Model Incubators are guaranteed to give satisfaction. 
ESSEX-MODEL MIDDLE-PRICE INCUBATORS. 1911 Model. This is a line of Middle-Price Incubators for those earnest poultry

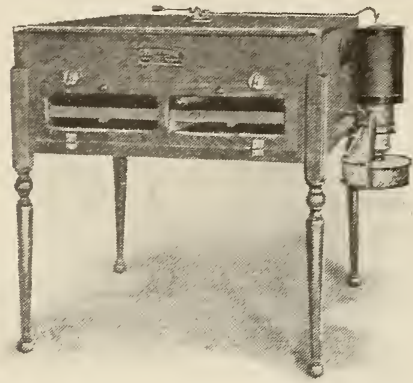
keepers who want nothing but a reliable hatcher, but who feel that they can hardly afford to invest in the higher-priced, more highly finished, "Standard" machine.

These Middle-Price Incubators are made of wood, covered with heavy enamelled rolled steel, finely finished. They are double walled; the space between being packed with cotton batting. The tops are also packed with several thicknesses of the same material to protect them from changes of outside temperature. The windows are of double glass with air space.

The heater, the Thermostat, the lamp rest, the shield and the deflector are similar to those used on the "Standard" machines described on previous page.

The heating and ventilating principle used year after year in the "Standard" Model Incubator is in great part retained in these new Middle-price Machines; therefore their Hatching Qualities are unquestioned. The main feature that admits of their cheaper construction is the fact that they are made in great part of rolled steel-tops, sides, backs, and bottoms; the front being made of chestnut.

Compare the prices of these Middle-Price Incubators with the prices of any other high-grade machine that holds as many eggs, and you will find that these cost less by about one-half. If these incubators were made by less experienced workmen, and in smaller numbers, they could not be made to sell at anywhere near these prices.

The Essex-Model Middle-Price Incubators are guaranteed to give satisfaction.

ESSEX-MODEL MIDDLE-PRICE INCUBATORS FOR 1911.

No. A Holds 60 Eggs; Price, $\$ 9.00$.

No. B Holds 120 Eggs; Price, 12.00.

No. C Holds $200 \mathrm{Eggs;}$ Price, 19.00.

No. D Holds 300 Eggs; Price, 29.00.

Call at our store and examine these Midle-Price Hatchers. See how easily they work. Everything automatic. Nothing to do but to fill the lamp and trim the wick. They run themselves.

\section{ESSEX-MODEL COLONY BROODERS.}

\section{Es s e X-M ode 1 Brooders are} known wherever poultry is raised by reason of their splendid combination of Light, Heat, Ventilation, and Floor Space, so designed as to afford the young chicks natural conditions without natural $\mathrm{d}$ à $\mathrm{n}$ ge r s; providing ventilation without draughts; heat without oil fumes; light sufficient for their needs; but not so much as to allow a great variation in temperature between day and night; in an amount of floor space that is not equalled at the price in any other make of Brooder. They Mother the Chicks Better Than a Hen, because they possess the advantages without the dangers and discomforts of natural 
brooding. Like all other Essex-Model goods their construction is Superior.

The Hover in all Essex-Model Brooders may be lifted up for cleaning purposes, or to examine the chicks, without detaching it from the Brooder-one of the 1911 improvements not possessed by any other similar brooder. This adds to convenience and economizes labor, thereby making these Brooders worth much more to the user. It is so placed that if chicks crowd they are forced outside the hover and so prevented from sweating and taking cold. The hover possesses more heating space than any other; hence it accommodates more chicks. For use in brooding houses this hover and heater excel all others.

The double-hinged combination ventilating door and window (original with Model Brooders), is of great utility. The window can be raised or lowered at will, and no rain can get into the brooder when it is open. The window opening is covered with fine wire-cloth-rat-proof; while as a method of ventilation it is perfect. The roof is of boards covered with enameled rolled steel which is practically imperishable and affords no chance for the roof to warp by the action of sun and rain. Examine other Outdoor Brooders having roofs of boards and note the result.

All Essex-Model Brooders can be converted into Roost Coops by removing the Hover and placing roosts in position, with cleats at both ends. This saves buying a coop for the young chicks when they no longer need artificial heat.

Models A, B, and C are Outdoor Brooders.

The Model D Brooder is a combination Indoor and Outdoor Brooder of new design which has never been equalled as a practical chick raiser for inside use in cold northern winters and for outside use in warmer climates. It possesses a double roof the uses of which may be varied at will to meet changeable weather conditions. For the fancier or farmer who wishes to raise early chicks this is an ideal brooder.

\section{ESSEX-MODEL BROODER. Prices and Capacity.}

Model A Brooder, 75 to 100 Chicks, Price, $\$ 11.50$.

Model B Brooder, 100 to 125 Chicks, Price, $\$ 14.00$.

Model C Brooder, 150 Chicks, Price, $\$ 17.00$. Model D Brooder, 75 to 100 Chicks, Price, $\$ 13.00$.

Send for complete catalogue of Essex-Model Incubators and Brooders.

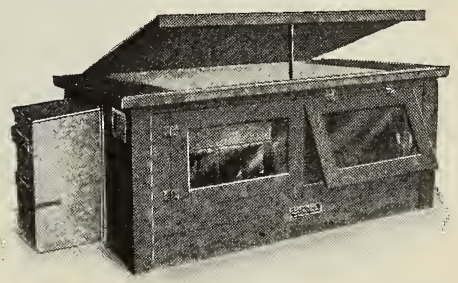

CONKEY'S ROUP CURE. Package, Postpaid, 50c; Six, \$2.75.

Lice Killer. Large package, 25c, postpaid, 40c.

Lice Spray, 1 qt., 40c.

Champion Leg Bands, 12 for $15 \mathrm{c}$; 50 for $50 \mathrm{c} ; 100$, 80c. Postpaid.

No. 2 Suspended Incubator Thermometer, 60c, postpaid.

No. 7 Brooder Thermometer,50c, postpaid. Model Nutrine Chick Salts.

5-1b. package, sufficient for 50 pounds Beef Scrap, or 100 lbs. mash, full directions with each package. By express, $\$ 1.00$.

Crushed Oyster Shells, 100-1b. bags, 75c.

Grit Hen or Chick size, 100-1b. bags, 70c.

Drinking Fountain, Galvanized Iron, 1 qt., 25c.

Drinking Fountain, Galvanized Iron, 35c.

Grit and Shell Feeding Box, 50c.

Sulphur Candles, $10 c-3$ for $25 c$. 


\section{CHOICE VARIETY OF FLOWER SEEDS.}

Let me remind my friends that Flower Seeds, being for the most part very small, require extra precaution in $t h \mathrm{e}$ preparation of the soil, depth of planting, and protection from extremes of cold and wet. Do not. as a rule, plant in the open ground before the weather has become settled; b e t t er wait until the middle of May. Before planting, the soil should be made very fine and be well enriched. For the smaller varieties, such as pansies, the rows may be from ten to twelve in ches apart; the largest upright varieties, such as zinnias a n d marigolds, the rows should be fifteen to eighteen inches apart; while for running

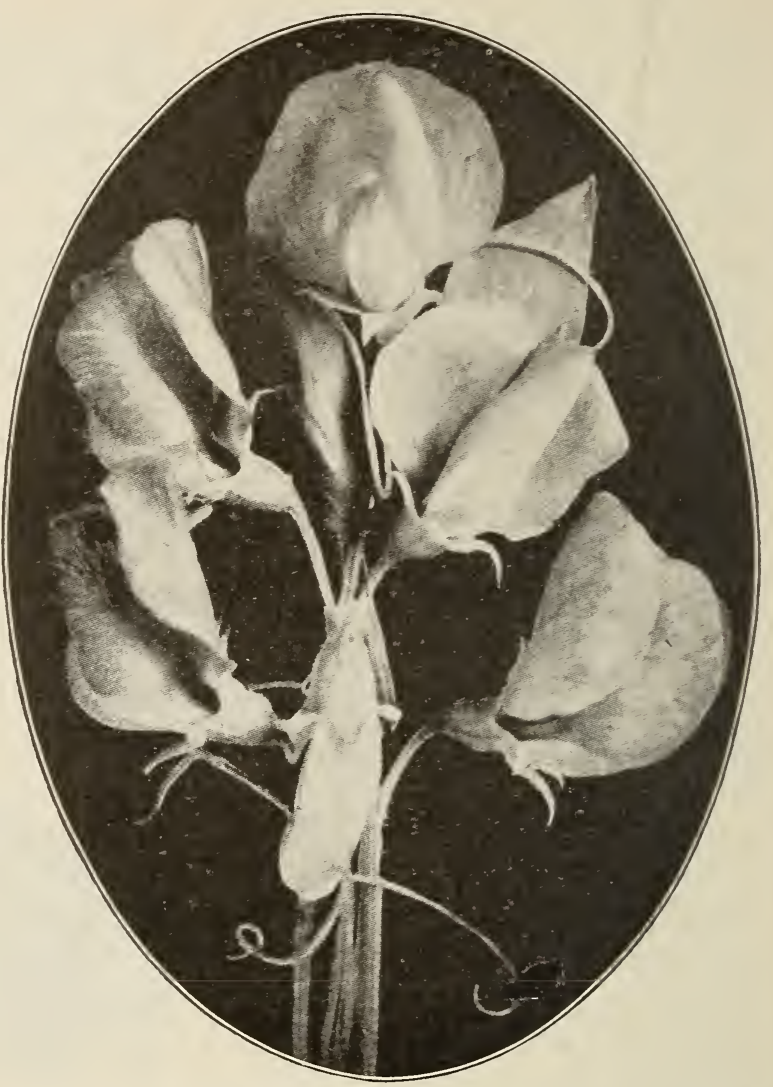
varieties, such as verbenas, the rows may be two feet apart. Seed the size of sweet peas may be planted one and a half to two inches deep; the very smallest seed should be planted barely under the surface, having fine earth sifted over them, and slightly packed with the hand, or a strip of board pressed upon it. It will keep the moisture in and facilitate vegetation if a newspaper is spread over the surface after planting, and kept down with stones for a few days. Thin out the plants when very small, with a bold hand, and after they have attained the height of two inches, thin again boldly. Give each plant plenty of room, according to its habit of growth. A common mistake is to crowd too much. Special rates when large amounts are ordered by clubs. Terms to dealers on application.

"B." Biennial; "P." Perennial.

The letter "A." annexed to the name of varieties signifies Annual; 
ANNUALS grow, bloom, and die the first year from seed; BIENNIALS bloom the second year from seed, and then die, though many, if sown early in the spring, will flower the first year. PERENNIALS usually bloom the second year from seed, and continue to grow and bloom for many years; some will also bloom the first year if sown early.

All Flower Seeds sent POSTPAID at Catalogue Price.

\section{ACROCLINIUM. (A.)}

Everlasting.-A very pretty, half hardy annual producing white and rose colored, double, daisy-like flowers, about one and one-half inches in diameter. These are the "Immortelles" so desirable for wreaths and winter bouquets. Height fifteen inches. Mixed, Pkt. 5c.

\section{AGERATUM. (A.)}

A beautiful hardy annual. The flowers borne in dense clusters are very useful for bouquets and the plants are very attractive in the garden. The different varieties are from six inches to two feet high and are covered with bloom nearly all summer. Mexicanum. Light blue, about twenty inches high. Pkt. 5c.

\section{SWEET ALYSSUM. (A.)}

This is one of the finest hardy annuals we have, and is beloved by many on account of its modest blossoms, very similar to white ForgetMe-Nots. It is pleasantly fragrant, and just the thing for personal adornment or for the breakfast table. It begins to blossom early in the season and blooms more or less constantly until fall. It is a neat, thrifty, healthy grower and should be cultivated by every one who wants an all-around good plant. Sow the seed wherever they are to remain. If too thick, thin out. Pkt. 5c; r/2 Oz. 15c (enough for a row $40 \mathrm{ft}$. long): Oz. 25c. Little Dorrit, new, fine. Pkt. 5c; Oz. 40c.

\section{ARISTOLOCHIA SIPHO.}

Dutchman's Pipe.-A vigorous growing climber, with curiously shaped purple-brown flowers and very large, heart-shaped leaves which have a tropical appearance; very effective for verandas. There is no better hardy climbing vine for shade or screen purposes. No insects or other troubles seem to mar its deep green foliage. Hardy perennial; grows from fifteen to thirty feet high. Pkt. 10c.

\section{ASTERS. (A.}

Queen of the Market.-Plants about one foot high, bearing from ten to fifteen finely formed flowers on long and graceful stems; blooms very early. Best for early cutting. White, Pink, Light Blue, Crimson. Pkt. $5 \mathrm{c} ; \mathrm{Oz} .75 \mathrm{c}$.

Truffaut's Perfection Peony Flowered.-The plants are about two feet high and produce large, perfectly formed and brilliantly colored flowers, with petals curving upward and inward, forming blooms of great beauty. The different colors come quite true to name. Mixed, Pkt. 5c.

Giant Comet, or Poodle Asters.-This class is one of the handsomest of the tall-growing sorts. The plants grow about 18 in. high and bear in great abundance their immense flowers. These flowers, with their long, twisted petals, strikingly resemble Japanese Chrysanthemums. Giant Comet, Mixed. Pkt. 10c; $1 / 8 \mathrm{Oz} .20 \mathrm{c} ; \mathrm{Oz}$. \$1.25. Giant Comet, Pure White. Pkt. 10c; Oz. $\$ 1.25$. 


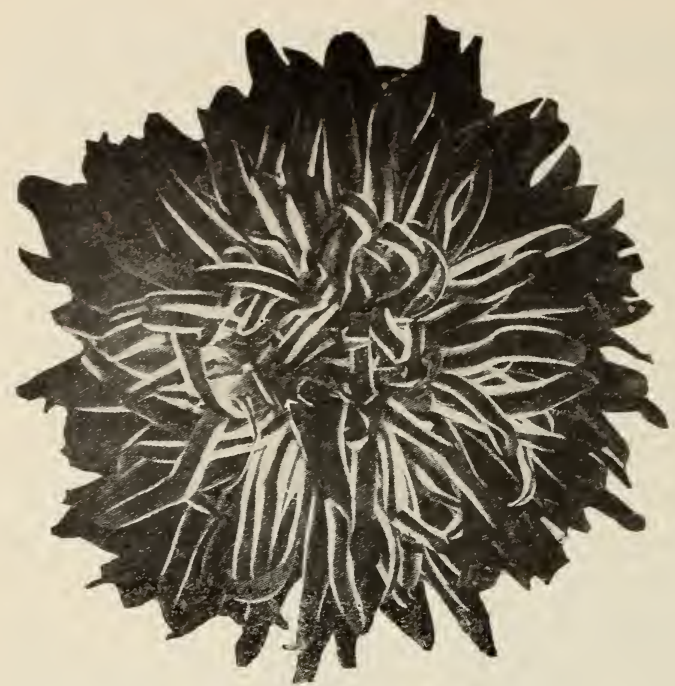

Aster, Comet, Ruby and White.-This strikingly beautiful novelty, of the same habit as the other varieties of this popular class of aster, originated from the Ruby Giant Comet Aster introduced a few years ago. Its peculiar color is quite unique among all asters. It is equally valuable for bedding, potting and cutting purposes. Pkt. $15 c$.

W. H. B. Gian $t$ Branching Asters.Beautiful Asters for cut flowers. Quite different in several respects from any Aster known. The branching habit is accompanied with great vigor of growth and profusion of bloom. The flowers are very large, very double, borne on long stiff stems, and the colors are clear and handsome. Pure White. Indigo, Lavender, Crimson, Mary Semple, Flesh Pink, Mixed, Dark Scarlet. Price: Pkt. (100 seeds) $10 \mathrm{c} ; 1$ pkt. each of the 7 for $50 \mathrm{c}$. Per $1 / 8 \mathrm{Oz}$., each, $25 \mathrm{c}$.

Ostrich Plume Aster.-A magnificent Aster, freely-branching. with long-stalked, graceful, fine double flowers of immense size, composed of very long, narrow, loosely curled florets, sugestive of a curled ostrich plume. Exceptionally handsome as cut flowers. Pure White, Rose, Light Blue, Crimson. Pkt. 10c; One Pkt. each of four, 25c.

BALSAM. (A.)

Known as Lady Slipper and Touch-me-not. Balsams have been so much improved by cultivation that, with good seed and proper care, a single flower is the exception now rather than the rule. Hardy annual; one to two feet high. Pkt. 5c.

CANTERBURY BELL. (B.)

Campanula Medium.-Handsome, hardy biennial of stately growth, rich color and profuse bloom. Succeeds best in light, rich soil and in the fall should be transplanted or thinned to eighteen inches or two feet apart and given some protection in severe winter weather. Has large, bell shaped flowers which are strikingly effective, colors white and various shades of violet. rose, lilac and blue. Height two to four feet. One of the wild forms of Campanula is the "Blue Bells of Scotland." Double Mixed, Pkt. 5c; Single Mixed, Pkt. 5c.

\section{CALLIOPSIS OR COREOPSIS. (A.)}

Very showy border plants, producing in great profusion and for $\pi$ long time flowers which are bright yellow and rich brown, either self colored or with these colors and red contrasted.

Coreopsis Tinctoria.-Although a native plant this is one of the ir.st desirable of our garden flowers. It produces an abundance of brilliantly colored flowers, varying from clear yellow to deep rich brown, the two colors often being beautifully contrasted in the same blossom. They are borne on long, graceful stems and are very desirable for decorative purposes. Very hardy and profuse blooming annual; two to three feet high. Fine Mixed, Pkt. 5c. 
Lanceolata grandifiora. (P.) - A hardy perennial, blooming the first year and producing on long stems a constant succession of very rich bright yellow flowers about three inches in diameter; exceedingly valuable for decorative purposes. Pkt. 10c.

CANARY BIRD FLOWER. (A.)

Tropœolum canariense.-A beautiful climber with small, curiously shaped canary colored blossoms. Will bloom freely from July until killed by frost. Tender annual. Height about twenty feet. Pkt. 5c.

\section{CANDYTUFT. (A.)}

Iberis. Showy, branching plants about fifteen inches high. Considered indispensable for cutting and very effective in beds, masses or rockeries. If shown in spring the plants will bloom from July to September, or if in the fall will blossom from May to July. Hardy annual.

Rocket.-Giant Empress.-Extra large white trusses; a great improvement in the size and quality of the flowering trusses over the common white variety. Fine Mixed, Pkt. 5c. Giant Hyacinth, Pkt. 5c.

Dwarf Mixed, Pkt. 5c.

\section{CARNATION.}

Marguerite.-The plants of this wonderfully fine strain may be made to bloom in four months. The flowers are large, double, very fragrant and appear in very attractive shades. One of the best "pinks" in cultivation. Pkt. $5 \mathrm{c}$.

Double Florists' Pink.-Plumarius Scoticus fi. pl.-This is the double form of common garden, grass or clove pink and though so common is one of the best of our hardy garden perennials. Pkt. 25c.

\section{CASTOR BEAN.}

(A.)

Ricinus.-Tall majestic plants for lawns, with leaves of glossy green, brown, or bronzed metallic hue and long spikes of scarlet, or of green, prickly fruit. Makes a rapid, vigorous growth in rich soil. Tender annual; six to fifteen feet high.

Zanzibariensis.-A comparatively new species of wonderfully vigorous growth, the plants growing from ten to fifteen feet high. Leaves have a brilliant lustre, measure about thirty inches across, and in different plants range from bright green with green stems to deep bronze with dark red stems. Mixed Varieties, Pkt. 5c.

\section{CENTAUREA. (A.)}

Marguerite.-A sweet scented, white Centaurea, about as large as a medium sized carnation. It is a sport from Centaurea Odorata and the plants are about eighteen inches high. The flowers are beautifully lasiniated and produced on long stems; their lasting quality after being cut is remarkable. Hardy annual. Pkt. 5c.

Imperialis Mixed.-An excellent sweet scented variety. The flowers are finely laciniated and are about the size of a carnation. They have long stems and keep well after cutting. The colors range through whit, rose, lilac, purple and yellow. Hardy annual; about eighteen inches high. Pkt. 10c.

Bachelor's Button, Double Mixed, Pkt. 5c.

Dusty Miller. These are planted for bedding, not for flowers.

Candidissima, leaves silvery white, Pkt. 10c.

Gymnocarpa, silver gray foliage, Pkt. 5c.

\section{DAISY. (P.)}

The Daisy has been so far improved by selection and careful cultivation, that good seed will give at least eighty per cent of double flowers that are as large as any of the named sorts that are propagated by division of the roots and are sold at high prices. The plants bloom well in the house and are splendid for early spring and summer flowering when planted in a slightly shaded situation. Double Rose (Longfellow), Finest strain, Pkt. 10c; Double White, Pkt. 10c; Double Mixed, Pkt. 5c. 


\section{ESCHSCHOLTZIA. (A.)}

California Poppy.--The state flower of California. A genus of the Poppy family, fully as valuable as the common Poppy for garden ornamentation as it blooms almost continuously throughout the season. A bed of these in full bloom gives a brilliant color effect. Hardy annual; height, except Bush, one foot.

Bush.-A new and distinct variety of unusual merit. Leaves are coarse and larger than the common kinds. Flowers are about three inches in diameter and are formed of broad, bright yellow petals with wavy edges. Stems ten inches long. Height of plant about two feet. Pkt. 5c. Fined Mixed, Pk. 5c.

\section{FOXGLOVE. (B.)}

Digitalis.-Grows to the height of three to four feet, affording dense spikes of brilliantly colored flowers which are terminal and half as long as height of plant. Colors white, lavender and rose. A valuable flower in every perennial garden; does not usually blossom until the second year. Hardy biennial or perennial. Fine Mixed, Pkt. 5c.

\section{FORGET-ME-NOT. (P.)}

Myosotis.-A favorite old-fashioned flower, bearing in profusion clusters of blue blossoms. It thrives well in the shade or open border. Hardy perennial. Victoria, Pkt. 5c.

\section{COLUMBINE. (P.)}

Aquilegia.-Every well regulated garden has a space devoted to hardy perennials and no bed of perennials would be complete without a due proportion of columbines. They are of the earliest culture and when once established will furnish for many years a magnificent display of the hadsomest flowers each spring and summer. The beds should be kept clean of weeds and given each year a liberal dressing of well rotted manure. Hardy herbaceous perennials; two to three feet high. Pkt. 5c.

FOUR O'CLOCK.

(A.)

Marvel of Peru.-The plants are large and each needs three or four feet of space each way for its best development. The flowers are funnel shaped, white, red, yellow or striped with these colors, open about four o'clock in the afternoon, remain open all night and generally perish before noon the next day. The abundance of new flowers produced daily affords a constant succession of fine blooms. The French call it Belle de Nuit, "Beauty of Night." Will grow in any common garden soil. Sow seed in open ground. Hardy annual; two feet high. Mixed Pkt., 5c. Mixed Double, best and finest colors, Pkt. 5c.

\section{GAILLARDIA. (A.)}

Showy plants, flowering the first year and among the gayest ornaments of the garden.

Picta Lorenziana.-For general decorative purposes as well as for bouquets, this is invaluable. The gay colored flowers are abundantly produced from July even until hard freezing weather. Hardy annual; one foot high; with root protection in winter is often treated as a per. ennial. Sulphur, orange, claret and amaranth mixed. Pkt. 5c.

\section{GOURD. (A.)}

Cucurbita.-A tribe of climbers with curiously shaped and colored fruit. Being of rapid growth they are much used for covering old fences. trellises, stumps, etc. Tender annual; ten to twenty feet high. Mixed Pkt. 5c.

HOLLYHOCK. (P.)

The modern hollyhock is entirely different and more beautiful than the plant of twenty years ago, being much more compact in growth, the flowers larger, richer colored and the double varieties are fuller and of 
better form. For a background to a flower garden there can be nothing better. Hardy perennial; five feet high.

Chater's Finest Mixed.-Double varieties of the greatest perfection. Pkt. 10c.

\section{JOB'S TEARS. (A.)}

Coix Lachryma.-Curious ornamental grass with broad, corn-like leaves and seeds of a light slate color. Valuable for the formation of winter bouquets in connection with everlasting flowers. Strings of handsome beads are made from the seeds. Hardy annual; three feet high. Pkt. 5c.

\section{KOCHIA TRICOPHYLIA. (A.)}

An easily grown annual which should be sown early when the trees are coming out in leaf. The plants are always of globe-like form, branching freely, the stems being covered with delicate light green foliage. Early in the fall the ends of the shoots are thickly set with small bright scarlet flowers, the bushy plants resembling balls of fire. Very showy when planted singly and there is nothing handsomer for a summer hedge. Pkt. 5.

\section{LARKSPUR. (A.)}

Very beautiful, hardy annuals, producing dense spikes of flowers, which are very decorative, either in the garden or when cut for vases. Set 10 inches apart. Pkt. 5c.

Candelabra-formed, Mixed, Pkt. 5c; Consolida, Emperor,Mixed Double

LOBELIA. (A.)

Strikingly pretty, profuse blossoming plants; the delicate, drooping habit of the Erinus varieties renders them fine for hanging baskets, while the compact sorts, forming little mounds of blooms, are splendid for beds, edgings, etc. Compacta. Bedding Queen. Dark Blue. Pkt. 5c.

\section{MARIGOLD. (A.)}

No flower garden seems complete without this fine old fashioned plant. The African varieties are tall, usually about three feet. while the French are more dwarf; all are desirable. Start the seed early indoors and transplant six inches apart as soon as danger of frost is over. Hardy annuals; in bloom till frost comes.

African El Dorado, Double.-Flowers about three inches in diameter, imbricated, extremely double and in tints of primrose, orange and gold. Pkt. 5c.

\section{MIGNONETTE. (A.)}

A well known hardy annual producing dense spikes of exceedingly fragrant flowers. If sown at intervals in spring and early summer it will bloom till killed by frost. Seed sown in autumn will bloom early the following spring. Thrives best in a cool temperature. Hardy annual; one foot high.

Machet.-Of dwarf and vigorous growth, with numerous stout flower stalks, terminated by massive spikes of red flowers. One of the very best for pot culture. Pkt. 5c.

\section{Golden Queen, Pkt. 5c.}

\section{MOON FLOWER. "(A.)}

Ipomœa Grandiflora Alba.-Will grow thirty to forty feet in a single season and be covered with its large, white flowers, every evening and cloudy days. The hard outer coat of the seed should be cut through with a sharp knife, care being taken not to cut any deeper than the hard shell and the seed planted about one inch deep in moist soil in a box or pan and set in a warm place. If the soil be kept moist, germination will take place in about two weeks. After the plants are up, plant outdoors in a sunny situation when danger from frost is past. Also known as Ipomœa Noctiflora. Pkt. 10c. 


\section{MORNING GLORY-GIANT JAPANESE MIXED. (A.)}

Flowers of immense size, some are brilliant red or rich blue; others are equally brilliant, with broad margins of clear white; some are striped and dotted with blue or red on white or lemon yellow ground, others are clouded with blue and red; the foliage in some plants comes plain green, in others it is mottled with white and shades of yellow or yellowish-green. Pkt. 5c.

\section{MOURNING BRIDE. (A.)}

(Scabiosa or Sweet Scabious.) This is one of the most attractive of the old fashioned flowers. Its great abundance and long succession of rich colored fragrant blossoms borne on long stems make it one of the most useful of the decorative plants of the garden. It has been greatly improved of late years, producing larger and more double flowers of greater variety and brilliancy of color than in the old type. Hardy annual; twelve to eighteen inches high. Double Mixed. Pkt. 5c.

\section{NASTURTIUM. (A.)}

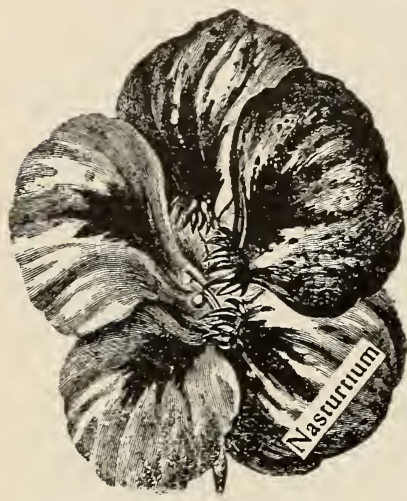

Dwarf Nasturtiums.-Tropœolum Minor.A bed of dwarf nasturtiums in the yard is very brilliant and attractive, blooming all the season. The plants are so evenly dwarf that they are often used for aborder. Hardy annual: about one foot high. Mixed Pkt. 5c; Oz. 15c.

Nasturtium.-Tall or trailing. Mixed Pkt. 5c: Oz. 15c.

\section{NASTURTIUM.}

Tall Chameleon ......... $\$$ Pkt. $\quad$ Oz.

Tall Lucifer, Lobianum .... $\quad .05 \quad .15$

Tall Black Prince ......... .05 .15

Dwarf, Tom Thumb Chameleon.05 $\quad .15$

Dwarf, Tom Thumb Empress India ................ .05

Dwarf, Tom Thumb Vesuvius ...................... .05

$\begin{array}{lll}\text { Dwarf, Queen of Variegated Leaves, Brilliant Crimson.... } & .10 & .25\end{array}$

\section{PANSY.}

Queen of the Giants.-Mixed.The pansy is growing in popularity every year, with it the demand for giant, rich colored blossoms is increasing.

I am offering a strain of seed grown by one of the leading European pansy specialists, which can be depended upon to meet with all the requirements as to form, color and size.

Plants are distinguished by their robust growth and form, compact bushes of round shape, with strikingly large, healthy foliage.

The improved five spotted flowers which on long, vigorous stalks surmount the foliage in the most graceful manner, are of enormous

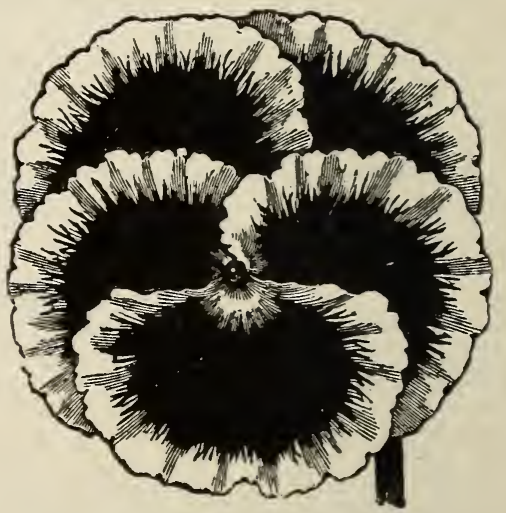

size, perfectly round form, original 
structure and unusual substance. The individual petals are exceedingly broad and cover each other in such a manner as to make the flowers appear almost double. With most of the flowers the border of every petal being conspicuously undulated and curled, which gives the flowers, a striking and very peculiar appearance entirely new to this class of plants. Pkt. 25c; $1 / 8$ Oz. $\$ 1.00 ; O z . \$ 7.00$.

Badger Mixed.- My own mixture, finest varieties. Pkt. $15 \mathrm{c} ; 1 / 8 \mathrm{Oz}$. $80 \mathrm{c} ; \mathrm{Oz} . \$ 6.00$.

Mammoth Five Spotted.-From named varieties. The immense flowers of this class resembling the Cassier, but being of almost double the size, full round form and comprising the most magnificent colors. Pkt. 5c; $1 / 8$ Oz. $75 \mathrm{c} ;$ Oz. $\$ 4.00$.

Giant Lord Beaconsfield.-Velvety purple violet, the top petals have a white margin. Pkt. 10c; I/8 Oz. 40c.

Giant Golden Queen.-Pure Yellow. Pkt. 10c; 1/8 Oz. 30c.

Giant Snowflake.-Pure White. Pkt. 10c; 1/8 Oz. 30c.

Giant Vulcan.-Color, bright dark red, each petal being marked with a very large dark blotch. The flowers are of large size and good substance and the edges of the petals are curled like those of the "Masterpiece" from which it is a selection. Pkt. 25c; $1 / 8 \mathrm{Oz}$. $\$ 1.25$.

Giant Psyche.-Each flower is elegantly curled and undulated and in every respect a beauty in form and color. The characteristic five velvety violet blotches or eyes are surrounded by a broad white edge. Pkt. 15c; $1 / 8 \mathrm{Oz}$. $75 \mathrm{c}$.

Giant Cassier Superb Strain.-This is a fine mixture of pansies marked with three or five blotches on rich background, the flowers are very large, round and borne on stiff stalks. This mixture. contains a great many red shades. Pkt. $15 \mathrm{c} ; 1 / 8$ Oz. $50 \mathrm{c}$.

Giant Odier or Five Blotched.-Of extraordinary beauty and perfect form, unsurpassed for richness of color.-Pkt. 15c; $1 / 8 \mathrm{Oz}$. 40c.

\section{PHLOX DRUMMONDI (Large Flowering). (A.)}

Unequaled in the magnificent display of their many and brilliantly colored flowers. They will grow even in poor soil, but in order to develop to their highest perfection, must have rich soil and must be given room. Plants from seed sown in open ground in fall or early spring will begin flowering about July 1 , and be literally covered with bloom until autumn. Unsurpassed for masses of separate colors or for bouquets. One foot high. Pure White, Pkt. 5c; Dark Red, Pkt. 5c; Finest Mixed, Pkt. 5c.

PETUNIA. (A.)

Large flowering. Mixed, Pkt. 15c; Choice Mixed, Pkt. 10c.

\section{PINKS. (B.)}

(Dianthus). Hardy and half hardy biennials and perennials, but nearly all blooming the first year from seed; of easy culture. Seeds may be sown in the open ground where they are to remain, but better results are obtained, in the north, if plants are started in the house. Chinese Double Mixed, Pkt. 5c; Heddewig's Double Mixed, Pkt., 5c.

PORTULACA.

Double Mixed, Pkt., 10c.

POPPY. (A.)

(Papaver.) Well known hardy annuals and perennials flowering in great profusion throughout the summer. As early in spring as ground can be worked sow the seed where flowers are to bloom and cover lightly, since if planted too deep the seed will not germinate and the annual varieties do not bear transplanting. To insure a continuous bloom during a long season the flowers should be cut regularly and no seed pods allowed to form. 
The Shirley.-This magnificent strain of Poppy affords during a long season flowers of the most charmingly delicate shades of colors imaginable, ranging from a pure glistening white through the pinks, reds and scarlets to the deepest crimson, the darker shades frequently being margined with white. Some of the petals are of silky texture, others look like tissue paper, some are plain, some crimped and some wavy. The flowers are exceedingly graceful and airy and lend themselves readily to bouquets which should be cut before the blooms are fully expanded; they will then keep fresh in water for several days. Pkt. 5c.

Tulip Flowered.-Produces bright scarlet flowers borne well above the foliage. The petals form a tulip-shaped cup and after a time black spots appear at the base of each petal. Hardy annual, one foot high. Pkt. 5c.

Double, Fringed White, Scarlet Edges, Pkt. 5c.

Carnation, double mixed.-Large, showy, double flowers of various colors, two feet high. Pkt. $5 \mathrm{c}$.

Double White Fringed.-This is the finest double white poppy. The plants are about two and one-half feet high, upright growing and so floriferous that a very fine showing is made. The blooms are from three to four inches in diameter, perfectly double, finely fringed and of the purest white. Pkt. 5c.

(Flowering Sage.) Among the most brilliantly colored of garden flowers and extremely useful for bedding; also valuable for pot culture. Blooms are borne in long spikes well above the foliage and are of fiery red, crimson or blue color, continuing in flower a long time. Start early in heat and transplant into light soil one to two feet apart. Tender perennials; but bloom the first season; height two to three feet. Fireball, extra fine, Pkt. 15c; Bonfire, Pkt. $10 \mathrm{c}$.

\section{SALPIGLOSSIS.}

Very showy bedding or border plants with richly colored, funnel shaped flowers, which are purple, scarlet, crimson, yellow, buff, blue or almost black. beautifully marbled and penciled. The seed may be sown indoors by the middle of March, or later, or may be sown outdoors in early spring; useful for cutting. Blooms from August to October. Half hardy annual; about two feet high. Fine Mixed, hybrid varieties, Pkt. $5 c$.

\section{STOCK. (A.)}

(Mathiola.) The Stocks, though not thriving so well in America as they do in England, are indispensable where a fine display of flowers is wanted and are particularly valued for edgings, bedding and pot culture. To such perfection has selection brought them that good seed will give a large proportion of exceedingly double flowers. Average height, one and a half feet.

Double German Ten Weeks.-These favorite summer flowers are excellent for bedding out and afford fine blooms for cutting. Mixed, Pkt. 5c.

\section{SUNFLOWER. (A.)}

These stately, old fashioned flowers with the newer improved varieties are coming into special favor as a background for lawns and in front of high fences. Valuable also as a screen to hide unsightly places and sometimes used to mitigate the evil of adjacent swamp holes. Hardy annual. Sunflowers grow readily in almost any soil, but do best on light, rich limestone or alluvial land well supplied with moisture and not shaded by trees or buildings.

Double Chrysanthemum Flowered.-A tall plant growing seven feet high and blooming profusely all summer. Flowers are double, large, round, and resemble chrysanthemums. The color is a splendid rich golden yellow, quite free from any black center. Pkt. 5c. 


\section{SWEET PEAS. (A.)}

Trial Ground Mixture.-This is a mixture of all varieties on trial grounds last year. including most of the newer varieties, and those of the Spencer and Unwin types. Pkt. 5c;Oz. 10c; I/4 Lb. 35c; Lb. $\$ 1.00$.

Countess Spencer.-A grand large flower of finest form and most beautiful coloring. The flowers are not only of extremely large size, but are distinct in having the outer edges of the standard and wings beautifully crumpled or waved. The coloring is a silvery white, suffused with soft rose pink, which deepens at the outer edges and becomes still richer or more heavily suffused in cool weather. The plant is a strong, vigorous grower, and the large flowers are borne three and four upon long stiff stems. Per Pkt. 5c;Oz. $15 \mathrm{c} ; \mathrm{I} / 4$ Lb. $40 \mathrm{c} ; \mathrm{Lb} . \$ 1.25$.

Dorothy Eckford.-Pure white. Pkt. 5c; Oz. 10c.

King Edward VII.-Red. Pkt. 5c;Oz. 10c.

Countess of Radnor.-Lavender. Pkt. 5c;Oz. $10 \mathrm{c}$.

Flora Norton.-Blue. Pkt. 5c;Oz. 10c.

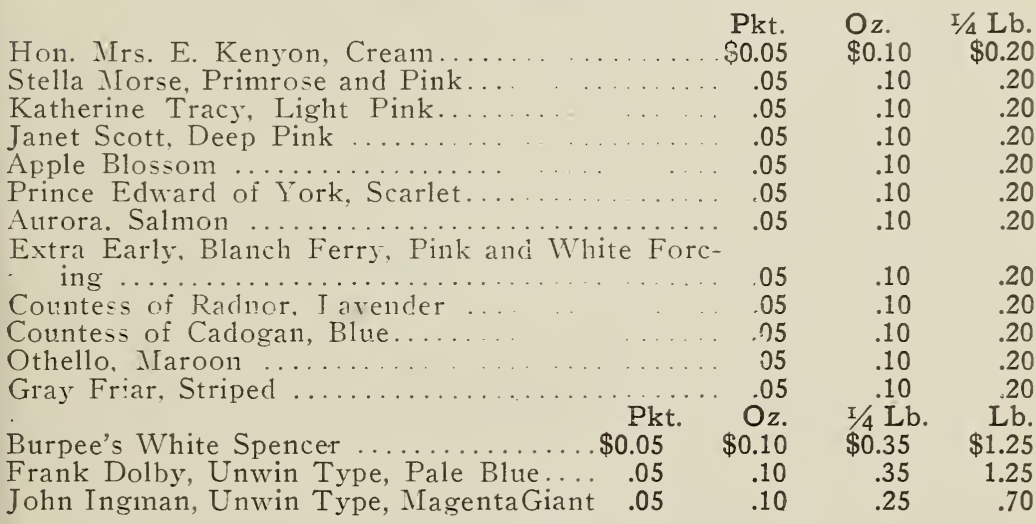

\section{VERBENA. (P.)}

The Verbena has been wonderfully improved during the past fifty years in form and size of flower truss and thrives particularly well in American soil. For masses in beds on the lawn no plant excels it. In the varieties may be found every color from white through lilac and rose to purple and very dark purplish blue. If sown in open ground in May they will bloom in August, but if started in the house in pots in winter they will flower sooner and may be had in constant bloom from June even until after the early, light frosts. Seed should be soaked in lukewarm water before planting and care taken that the soil be very rich. Verbenas can be grown from cuttings, but seedlings are more vigorous and produce more flowers, all being showy and often the clusters have a delicate fragrance. Half hardy perennial trailer which has gained much in popularity through treatment as an annual. Mammoth, Pkt. 5c; I/4 Oz. 35c.

\section{SWEET WILLIAM. (P.)}

(Dianthus Barbatus.) For display in the garden the Sweet William is unsurpassed. The plants produce a succession of flower clusters, thus affording splendid bloom for several weeks. The colors are exceedingly varied, ranging from white through many shades of rose, lilac, red, carmine, crimson, maroon, to nearly black, usually two shades to each plant. The seed can be planted in the spring in open ground and will blossom in the fall or the following spring; or it can be sown in August and will 
make fine blooming plants for the summer following. Hardy perennial; one and a half feet high. Pkt. 5c.

\section{ZINNIA. (A.)}

Very showy plants with large, double, imbricated flowers, which, when fully expanded might easily be mistaken for dwarf dahlias. There is much satisfaction in a bed of Zinnias, for when nearly every other fower has been killed by frost this plant is still in full bloom. Few flowers are more easily grown or bloom more abundantly throughout the season. Sow the seed early in spring, in open ground, and transplant to one and one-half feet apart in good, rich soil. Half hardy annual; about eighteen inches high. Splendid double varieties, extra selected mixed, Pkt. 5c; Double dark purple, crimson, Pkt. 5c.

\section{GRASS AND CLOVER SEEDS.}

Market prices fluctuate. Write for special quotations.

\section{BADGER LAWN GRASS SEED.}

Badger Lawn Grass Seed.-An unrivaled mixture of the purest and cleanest seed; it contains only the highest grade of grass suitable for the purpose of making a beautiful, durable, lasting lawn. My Badger mixed seed germinates quickly, roots deeply; this enables it to readily withstand the heat of summer and the severe cold of winter, showing a beautiful, rich green at all seasons ofthe year. Contains no annual grasses for making a quick show, but has only those which are hardy and lasting. A lawn once established from this seed lasts for years.

From six to eight weeks' time is all that is required to form a close, thick turf of rich, velvety green. For a perfect and enduring lawn of closely interwoven, firm, elastic turf, which will flourish under varied conditions of soil and climate and show a luxuriant, rich green growth throughout the year, plant Bofferding's Badger Lawn Grass Seed.

Quantities to use-1 lb. for 400 square feet, $100 \mathrm{lbs}$. for 1 acre. I sell by the pound instead of quart. One pound will measure nearly one and one-half quarts.

Badger Brand, per Lb., 30c; 10 Lbs. \$2.75. By express, purchaser's expense.

Special Mixed, per Lb., 25c; 10 Lbs., \$2.25. By express, purchaser's expense.

Shady Place Mixed, per Lb., 35c; 10 Lbs., \$3.25. By express, purchaser's expense.

Kentucky Blue Grass.-Can be used alone or mixed with white clover for lawn. Pure, clean seed. Per Lb., 30c; 10 Lbs., \$2.85. By express, purchaser's expense.

White Clover-Best for lawns. Sow at the rate of $5 \mathrm{lbs}$. per acre. Per Lb., 40c; 10 Lbs., $\$ 3.80$. By express, purchaser's expense.

Above prices do not include postage. If to go by mail add $8 \mathrm{c}$ per $1 \mathrm{~b}$.

How to Make a Lawn.-The preparation of the soil is very important in making a good lawn. As early as possible in the spring it should be thoroughly dug or ploughed to the depth of 10 to 12 inches and properly graded to the desired level. Remove all stones, sticks, sods, etc., harrow or rake it fine and roll it firm. It is impossible to get the scil too fine to receive the seed. After rolling, the soil will be ready for the seed. If the soil is poor, wood ashes, bone meal or pulverized sheep manure should be added after digging it up. Well-rotted stable manure is also good, but it often contains weed seeds. Sow the best seed obtainable: it is always cheapest in the end; use quantity as indicated by table on this page. It is best to sow seed liberally, not only so as to produce a lawn quickly, but because the best lawn seed produces fine-leaved grasses which should take entire possession of the ground at once, thus choking out and preventing the development of any weed seeds which are apt 
to be in all soils. Sow seed by hand, distributing it evenly, going both ways across the plot. After sowing, cover the seed by raking lightly, then roll. When the grass has become well rooted, use lawn mower. Keep the mower sharp, as if dull, it will pull and injure the grass. besides causing the lawn to have an uneven appearance. Never allow the grass to become so high that the mower will take off the first joint, as this is an injury. Mow as often as necessary; in growing weather at least once a week. Let the short clippings remain on the lawn, as they wither and dry and form a protection to the roots. When the clippings are long, they should be raked off; for besides being unsightly, they are also injurious. When dry and hot avoid cutting too close. In the early spring every lawn should be carefully rolled, to smooth and firm the soil and take out any unevenness caused during the winter by the heaving of the frost. During dry spells the lawn should be thoroughly soaked once a week in the evening or after the sunshine is off the lawn.

To Grass a Terrace.-Take for each square rod a pound of lawn grass seed, and mix it with about six cubic feet of good dry garden loam. Place it in a tub and add liquid manure, diluted with about two-thirds water until the mixture has the consistency of mortar. Make the slope perfectly even and smooth, water it well, then apply the paste in a thin, even coat.

Old lawns can be renovated by using half quantity of seed necessary to make a new lawn. Rake in the seed with a sharp tooth rake early in the spring.

Special Quotations.-I am always pleased to quote special prices to parks, institutions, golf clubs and others who require lawn grass seeds in large quantities.

\section{WHAT WE ARE DOING IS THIS.}

Furnishing raw fertilizer materials, enabling the growers to do their own mixing, eliminating the expense and handling of "filler" or "make weight" material usually found in mixed or prepared fertilizers.

When purchasing raw materials you are assured of getting full value for money expended and the satisfaction in knowing you are handling the "pure quill" or "substance instead of shadow," also that you are in a position to supply your soil with any of the ingredients separately.

These materials or Plant Foods are adapted for all crops or plants and are termed as follows, containing analysis given when in the pure form:

Nitrate of Soda (testing $15.5 \%$ available Nitrogen, of $95 \%$ Soda), supplied in (about) $200 \mathrm{lb}$. original import bags.

Muriate of Potash (testing $50 \%$ available Potash).

Sulphate of Potash (testing $48 \%$ available Potash).

The potash is supplied in $224 \mathrm{lb}$. original import bags.

Acid Phosphate "High-Grade" (testing 14 to $16 \%$ available Phosphoric Acid) supplied in $200 \mathrm{lb}$. bags.

\section{A FEW SUGGESTIONS ON HOME MIXING.}

When fertilizers are to be mixed together, pour the right quantity of each in a pile on the floor and turn them over two or three times with a shovel until they are thoroughly mixed. It is a good plan to run the whole through a sieve, which will completely mix the fertilizers. The mixing should not be done more than a week before the fertilizers are to be used, as the mixture may attract moisture and get hard if left too long after mixing. Any lumps found in the materials should be broken up with the back of a spade before mixing is started. 
On Market-Garden Crops, Tobacco, Potatoes, Onions, Cabbage, Tomatoes and Fruit:

$$
\begin{aligned}
& 100 \text { to } 300 \text { lbs. Nitrate of Soda. } \\
& 100 \text { to } 200 \mathrm{lbs} \text {. Muriate or Sulphate of Potash. } \\
& 300 \text { to } 600 \mathrm{lbs} \text {. Acid Phosphate. } \\
& \overline{500} \text { to } 1,100 \mathrm{lbs} \text {. per acre. }
\end{aligned}
$$

When using $300 \mathrm{lbs}$. Nitrate of Soda per acre mix $100 \mathrm{lbs}$. with the Potash and Phosphate and broadcast the remaining $200 \mathrm{lbs}$. in two equal dressings, two or three weeks apart during growing season. Send for pamphlet "Plant Food Facts."

Pure Bone Meal, 5 lbs., 25 cents; 25 lbs., 75 cts.; 100 lbs., $\$ 2.50$.

Pulverized Sheep Manure makes the richest and safest liquid manure. One pound to five gallons of water. $100 \mathrm{lb}$. bag, $\$ 1.50$.

Nitrate of Soda should be sown when plants are in growth. $25 \mathrm{lbs}$, $\$ 1.25 ; 100$ lbs., $\$ 4.00$.

Muriate of Potash, 25 lbs., $\$ 1.00 ; 100$ lbs., \$3.25.

Acid Phosphate, 10 lbs., 30 cts.; 100 lbs., $\$ 1.50$.

Sulphate of Potash, 10 lbs., 50 cts.; 100 lbs., $\$ 3.75$.

Badger Lawn Dressing. A complete manure for top dressing of lawns. Odorless, clean and convenient to use. Sow broadcast in early spring, just as the grasses are starting into growth. It will be found of benefit in producing a nice, healthy growth of turf. It is much easier to use than a top dressing of stable manure, which not only is unsightly but fills a lawn with weeds.

Price, by express or freight, 10 lbs., 50 cts.; 25 lbs., $\$ 1 ; 100$ lbs., \$3.

Floral and vegetable novelties and tried varieties which should be in every garden:

Aster.-Giant Comet Canary Bird, of a pure light Yellow Color. This novelty to surpass the variety Sunlight in perfection of form and general utility.

Aster.-Vick's New Scarlet. Fine.

Salpiglossis.-Emperor Mixed.

Cosmos.-Early Minnesota. The best early.

Nasturtium.-Tom Thumb, variegated leaved. Brilliant Crimson.

Poppy.-New, Double Fringed, White with Scarlet.

Pink.-Mephisto. Laciniated.

Pink.-Old fashioned garden. Spice or Grass Pink.

Ten cents per Packet. Fifty cents eight Packets.

Musk Melon.-Hoodoo.

Beans.-Round Pod Kidney Wax. Ten cents per Packet.

Parsley.-Fern Leaved.

Corn.-Golden Bantam. The best Sweet Corn. Ten cents per Pkt.

Beet.-Electric.

Radish.-New, half White Turnip.

Lettuce.-Unrivalled. Head.

Swiss Chard, or Spinach Beet, for Greens.

One Packet each, Vegetable collection, 35 cents.

Address all correspondence to W. H. Bofferding, 1221 Washington Avenue North, Minneapolis, Minn. 


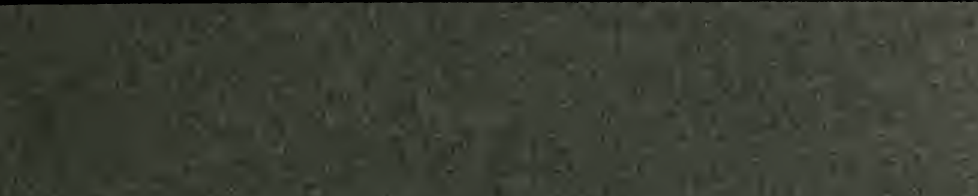




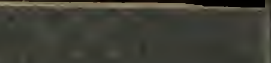

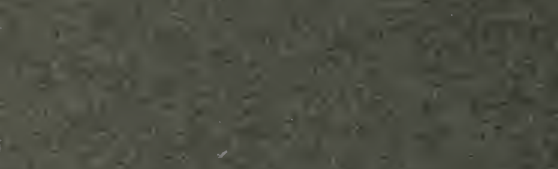

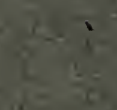

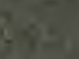

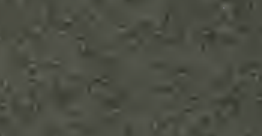

